Species Management Research Program

Prepared in cooperation with the Bureau of Land Management

\title{
Compilation of Information on Occurrence and Conservation Status for the Freshwater Mussel Fauna of Nebraska, Kansas, and Oklahoma
}

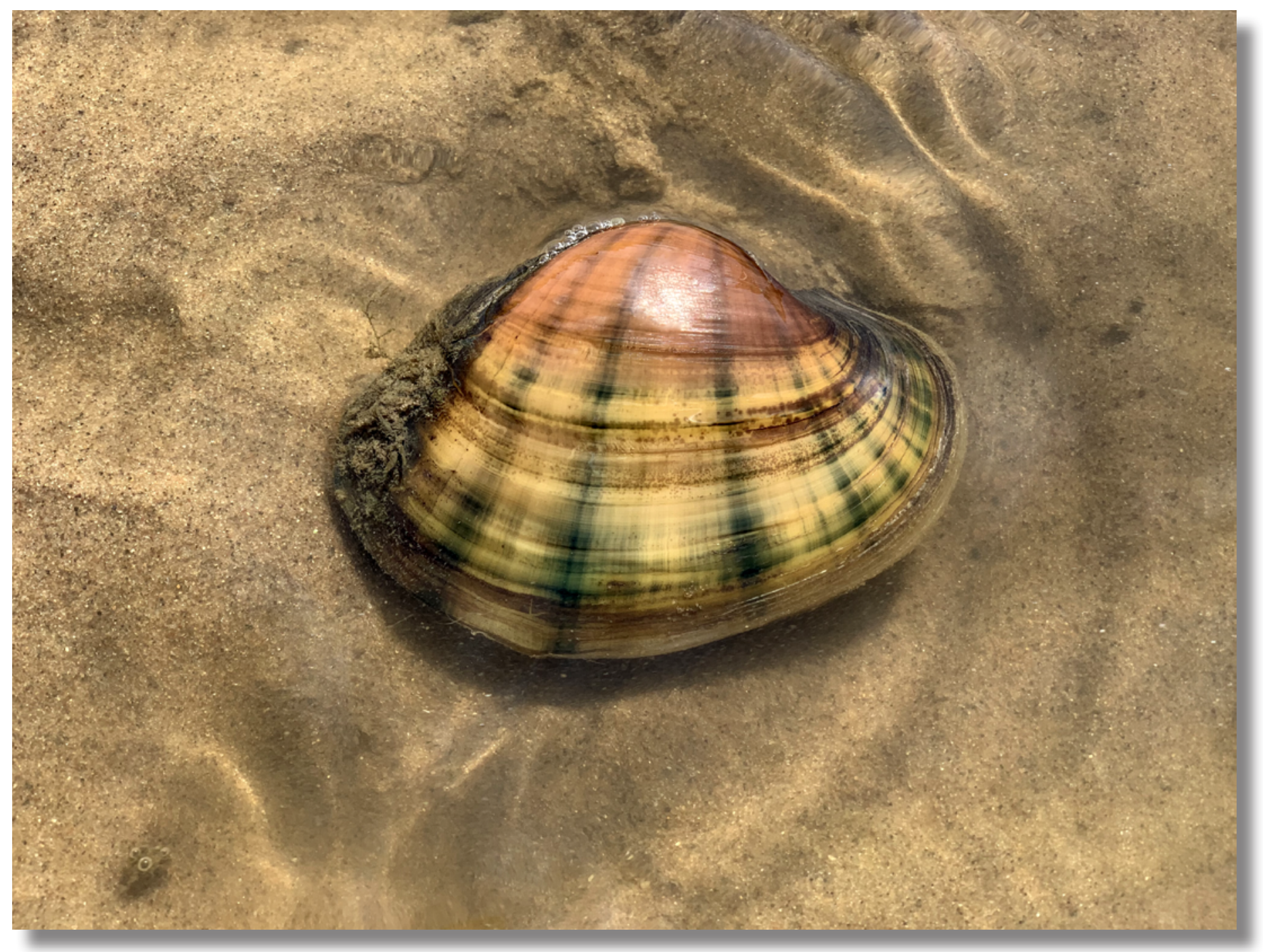

Data Series 1133 
Cover. The freshwater mussel Lampsilis cardium (plain pocketbook), one of the six focal species in the freshwater mussel assemblage evaluated for the project area, which covers Nebraska, Kansas, and Oklahoma. Photograph by Teresa Newton, U.S. Geological Survey. 


\section{Compilation of Information on Occurrence and Conservation Status for the Freshwater Mussel Fauna of Nebraska, Kansas, and Oklahoma}

By Natasha B. Carr and Tammy S. Fancher

Species Management Research Program

Prepared in cooperation with the Bureau of Land Management

Data Series 1133 


\section{U.S. Geological Survey, Reston, Virginia: 2021}

For more information on the USGS - the Federal source for science about the Earth, its natural and living resources, natural hazards, and the environment—visit https://www.usgs.gov or call 1-888-ASK-USGS.

For an overview of USGS information products, including maps, imagery, and publications, visit https://store.usgs.gov/.

Any use of trade, firm, or product names is for descriptive purposes only and does not imply endorsement by the U.S. Government.

Although this information product, for the most part, is in the public domain, it also may contain copyrighted materials as noted in the text. Permission to reproduce copyrighted items must be secured from the copyright owner.

Suggested citation:

Carr, N.B., and Fancher, T.S., 2021, Compilation of information on occurrence and conservation status for the freshwater mussel fauna of Nebraska, Kansas, and Oklahoma: U.S. Geological Survey Data Series 1133, 22 p., https://doi.org/10.3133/ds1133.

Data associated with this publication:

Fancher, T.S., and Carr, N.B., 2021, Distribution of a freshwater mussel assemblage in Kansas, Nebraska, and Oklahoma: U.S. Geological Survey data release, https://doi.org/10.5066/P9SBFZJU.

ISSN 2327-638X (online) 


\section{Acknowledgments}

Funding for this work was provided by the U.S. Department of the Interior, Bureau of Land Management. Assistance with data compilation was provided by Lucy Burris and Gordon Reese, formerly with the U.S. Geological Survey. We thank the Kansas Department of Health and Environment for providing the mussel survey data for Kansas and reviewing the draft data series. Reviews of the draft data series were provided by Teresa Newton and Nathan Kleist of the U.S. Geological Survey. 



\section{Contents}

Abstract

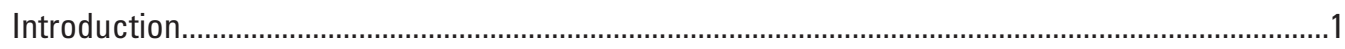

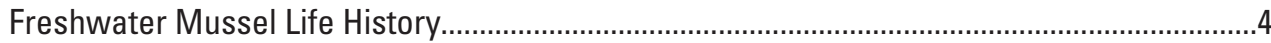

Freshwater Mussel Guilds ..........................................................................................

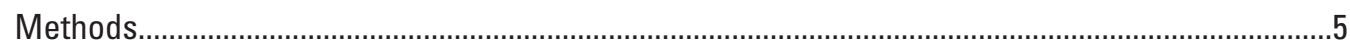

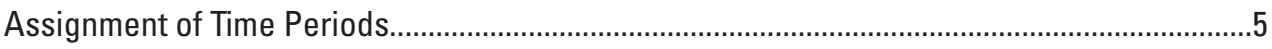

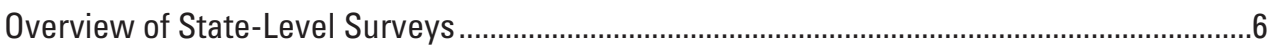

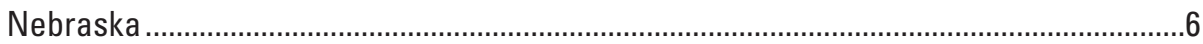

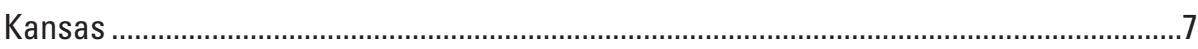

Oklahoma

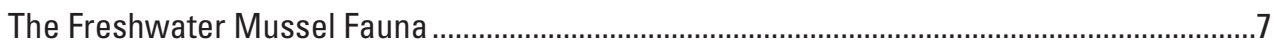

The Freshwater Mussel Assemblage ....................................................................................

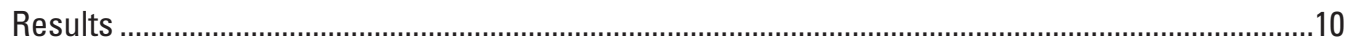

Conservation Status and Distribution Patterns of the Freshwater Mussel Fauna ..................10

Distribution of the Freshwater Mussel Assemblage ............................................................10

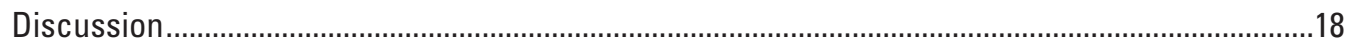

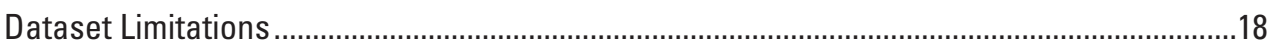

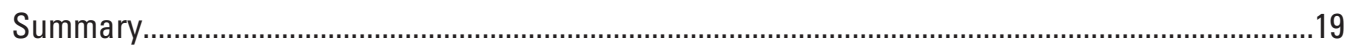

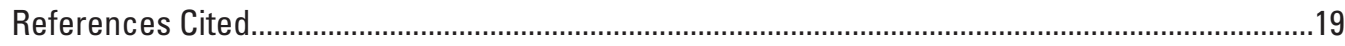

\section{Figures}

1. Map showing hydrologic subregions used for summarizing the contemporary distribution of the freshwater mussel assemblage in Nebraska, Kansas, and Oklahoma ....................................................................................................................

2. Map showing the distribution of Amblema plicata in Nebraska, Kansas, and

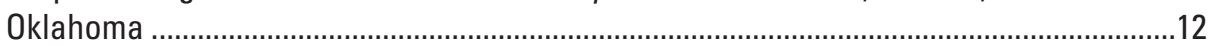

3. Map showing the distribution of Fusconaia flava in Nebraska, Kansas, and

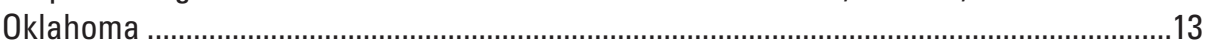

4. Map showing the distribution of Lampsilis cardium in Nebraska, Kansas, and

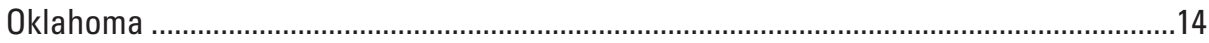

5. Map showing the distribution of Lampsilis teres in Nebraska, Kansas, and

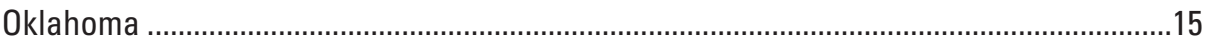

6. Map showing the distribution of Pyganodon grandis in Nebraska, Kansas, and

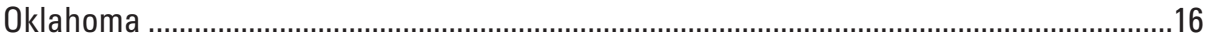

7. Map showing the distribution of Uniomerus tetralasmus in Nebraska, Kansas, and Oklahoma. 


\section{Tables}

1. Habitat association, life history strategy, thermal tolerance, and reproductive characteristics of species in the freshwater mussel assemblage mapped in Nebraska, Kansas, and Oklahoma.

2. Data sources, type, geographic extent, and survey time periods used for mapping the distribution of the freshwater mussel assemblage in Nebraska, Kansas, and Oklahoma

3. Number of occurrence records used for mapping the distribution of focal species in the freshwater mussel assemblage in Nebraska, Kansas, and Oklahoma

4. Distribution classes and conservation status for extant and extirpated freshwater mussels mapped in Nebraska, Kansas, and Oklahoma.. .8

5. Contemporary occurrence records for the freshwater mussel assemblage by subregions and subbasins in Nebraska, Kansas, and Oklahoma.

\section{Abbreviations}

GBIF Global Biodiversity Information Facility

KDHE Kansas Department of Health and Environment

REA Rapid Ecoregional Assessment

SGP Southern Great Plains

USGS U.S. Geological Survey 


\title{
Compilation of Information on Occurrence and Conservation Status for the Freshwater Mussel Fauna of Nebraska, Kansas, and Oklahoma
}

\author{
By Natasha B. Carr and Tammy S. Fancher
}

\section{Abstract}

The purpose of this data series is to compile information on the occurrence and conservation status of the freshwater mussel fauna of Nebraska, Kansas, and Oklahoma and to map the distribution of a freshwater mussel assemblage for the U.S. Department of the Interior, Bureau of Land Management Rapid Ecoregional Assessment (REA) program. The six focal species in the freshwater mussel assemblage are Amblema plicata (threeridge), Fusconaia flava (Wabash pigtoe), Lampsilis cardium (plain pocketbook), Lampsilis teres (yellow sandshell), Pyganodon grandis (giant floater), and Uniomerus tetralasmus (pondhorn). The focal species were selected using the following criteria: (1) the species are regionally significant, (2) occurrence records are sufficient to map the distribution of the species by hydrologic subbasins, (3) the assemblage includes species representing a range of State-level conservation priorities, and (4) the species are not listed as federally endangered or threatened. In addition, the species represent a broad array of life history strategies and habitat associations.

A total of 61 native species of freshwater mussels have documented occurrences within at least 1 of the 3 States, including 6 species that appear to have been extirpated from all the States and 6 species that may have been extirpated from at least 1 State. Of the 61 species, 8 species (including 3 potentially extirpated species) are listed as federally threatened or endangered and an additional 5 species are ranked as imperiled or vulnerable across their range. Approximately 80 percent of the native species known to have occurred within the three-State area have a secure conservation status, in comparison to only 40 percent of all freshwater mussel species or subspecies occurring within the United States. The compiled records for the contemporary period (1970-2017) documented the occurrence of 24 extant species in Nebraska, 42 in Kansas, and 48 in Oklahoma.

The contemporary distributions of the six focal species were mapped by subbasins and the larger hydrologic subregions. Historical records (prior to 1962) were also mapped but were limited. Amblema plicata, Fusconaia flava, and Lampsilis cardium were present in approximately one-third of all subbasins and slightly more than half of the subregions, primarily along the eastern portion of the three-State area. Lampsilis teres and Uniomerus tetralasmus were more widespread, occurring in close to half of the subbasins and about three-quarters of the subregions. Pyganodon grandis was the most widespread, occurring in about three-quarters of the subbasins and almost all subregions. There were very few subbasins with historical occurrences that lacked contemporary occurrences. The broad-scale distribution maps for the freshwater mussel assemblage presented with this report are intended to contribute baseline information for regional assessments, such as the Southern Great Plains Rapid Ecoregional Assessment. Despite the limitations of the available data, such baseline information can be useful for identifying data gaps, monitoring future trends, identifying conservation priorities, and providing the larger context for more detailed watershed- or catchment-level studies. ScienceBase data release files associated with this data series are available at https://doi.org/10.5066/P9SBFZJU (Fancher and Carr, 2021).

\section{Introduction}

Regional assessments, such as Rapid Ecoregional Assessments (REAs) conducted by the U.S. Department of the Interior, Bureau of Land Management, provide multiscale information for a variety of management applications. The overarching purpose of the REAs is to "facilitate evaluation of the cumulative effects of management decisions on regionally important species and ecosystems at broad spatial scales" (Carter and others, 2017). Broad-scale assessments spanning jurisdictional boundaries can provide the larger context for local or State-level management decisions and can facilitate cross-jurisdictional coordination of management actions (Carter and others, 2017). REAs compile and synthesize datasets for one or more ecoregions and evaluate the effects of change agents (drivers of ecological changes that can affect natural resources, such as development, wildfire, invasive species, and climate change) on priority species (or species assemblages) and ecological communities, which are collectively referred to as conservation elements (Assal and others, 2015). 
The species evaluated as conservation elements by the REAs are intended to be representative of management issues not adequately addressed by evaluating the effects of change agents on ecological communities (Reese and others, 2017). The REAs use the term "species assemblage" in reference to two or more focal species from a taxonomic group (such as sagebrush-obligate birds, tree-roosting bats, or freshwater mussels) that use similar habitat types and are collectively evaluated as a unit. Although the concept of species assemblages in ecology usually refers to species co-occurring at a local site (for example, Haag and Warren, 2007), the REAs apply this concept to the distribution of focal species at broad spatial scales (such as mussel species co-occurring within subbasins across a region of interest).

Freshwater mussels (Bivalvia: Unionoidae) were initially identified as a potential conservation element for the Southern Great Plains REA because of population declines over the past century resulting from previous harvesting, aquatic development, pollution, and threats from invasive species, as well as vulnerability to climate change (Assal and others, 2015; Tweedy, 2015). Freshwater mussels are sensitive to altered flow regimes and degraded water quality (sedimentation and chemical contamination) resulting from channelization, impoundments, loss of riparian vegetation, and adjacent upland development including agriculture, energy production, mining, roads, and urbanization (Vaughn and Taylor, 1999; Haag, 2012; Haag and Williams, 2014). Of the approximately 300 freshwater mussel species that occur in the United States, it is estimated that 30 species or subspecies have become extinct, primarily as a result of dam installation (Haag and Williams, 2014). Close to 60 percent of extant species or subspecies are imperiled or vulnerable, including 93 species listed as federally threatened or endangered (NatureServe, 2020; U.S. Fish and Wildlife Service, 2020). Unexplained catastrophic declines of mussel populations in streams that otherwise support healthy fish and other aquatic invertebrate populations underscore the threats to mussel populations (Haag and Williams, 2014; Haag, 2019). Even widespread and common species have experienced population declines (Galbraith and others, 2018).

Freshwater mussels have many characteristics that make them suitable as indicator species, including broad interspecific variation in tolerance to contaminants and altered habitat conditions (Williams and others, 1993; Grabarkeiwicz and Davis, 2008). In addition, declines in the abundance and diversity of mussel faunas can have significant ecological consequences. Mussels often dominate the biomass of the stream benthos (Williams and others, 1993; Haag and Williams, 2014) and contribute to crucial ecosystem functions including stabilizing substrates, cycling nutrients, and providing food and habitat for other species (Angelo and others, 2009; Vaughn, 2010, 2018; Vaughn and others, 2004). Continued declines in populations of freshwater mussels could negatively affect such ecosystem functions (Galbraith and others, 2018).
Six focal species from the Interior Basin faunal group were selected to represent freshwater mussels in the project area (Tweedy, 2015): Amblema plicata (threeridge), Fusconaia flava (Wabash pigtoe), Lampsilis cardium (plain pocketbook), Lampsilis teres (yellow sandshell), Pyganodon grandis (giant floater), and Uniomerus tetralasmus (pondhorn). The focal species in the freshwater mussel assemblage were selected based on the following criteria: (1) the species are regionally significant (occur across all States in the ecoregion and are not narrowly distributed; Assal and others, 2015), (2) occurrence records are sufficient to map the distribution of the species by subbasin, (3) the assemblage includes species representing a range of State-level conservation priorities, and (4) the species are not listed as federally endangered or threatened. The freshwater mussel assemblage was assumed to be representative of other mussel species in the project area. The degree to which this assumption is valid depends, in part, on the spatial extent and ecological processes under consideration (Caro, 2010).

This data series summarizes information on the entire freshwater mussel fauna, and maps the distribution of the mussel assemblage, for Nebraska, Kansas, and Oklahoma (hereafter referred to as project area; fig. 1). Geospatial data on the distribution of freshwater mussels at broad spatial extents is typically only available at a coarse resolution corresponding to State boundaries (for example, NatureServe, 2020). To address the need for baseline geospatial data on the distribution and conservation status of freshwater mussels in the three-State project area, we compiled a list of all documented extant and extirpated freshwater mussel species and synthesized information on their distribution and conservation status. We used occurrence records to map the contemporary distribution of focal species in the freshwater mussel assemblage at two levels of nested hydrologic units: subbasins and subregions (U.S. Geological Survey and U.S. Department of Agriculture, 2013). Subbasins (fourth-level, 8-digit hydrologic unit) are nested within subregions (second-level, 4-digit hydrologic unit; fig. 1). All subregions in the project area are nested within two regions (first level, 2-digit hydrologic unit): the Missouri and Arkansas-White-Red regions. By mapping the distribution of focal species at a finer resolution and broader spatial extent than State-level distribution maps, this data series and associated data release (Fancher and Carr, 2021) address an information gap identified by the SGP REA (Assal and others, 2015; Reese and others, 2018).

The associated data release (Fancher and Carr, 2021) summarizes occurrence records for the freshwater mussel assemblage by the 8-digit hydrologic unit code, which identifies the region, subregion, and subbasin (see figs. 2, 3, 4, 5,6 , and 7 for graphical representations of the data release). For each subbasin, the data release provides occurrence information for each of the six focal species, including time period, data source, and number of occurrence records. Such multiscale baseline information can be useful for evaluating mussel population status and trends, identifying 


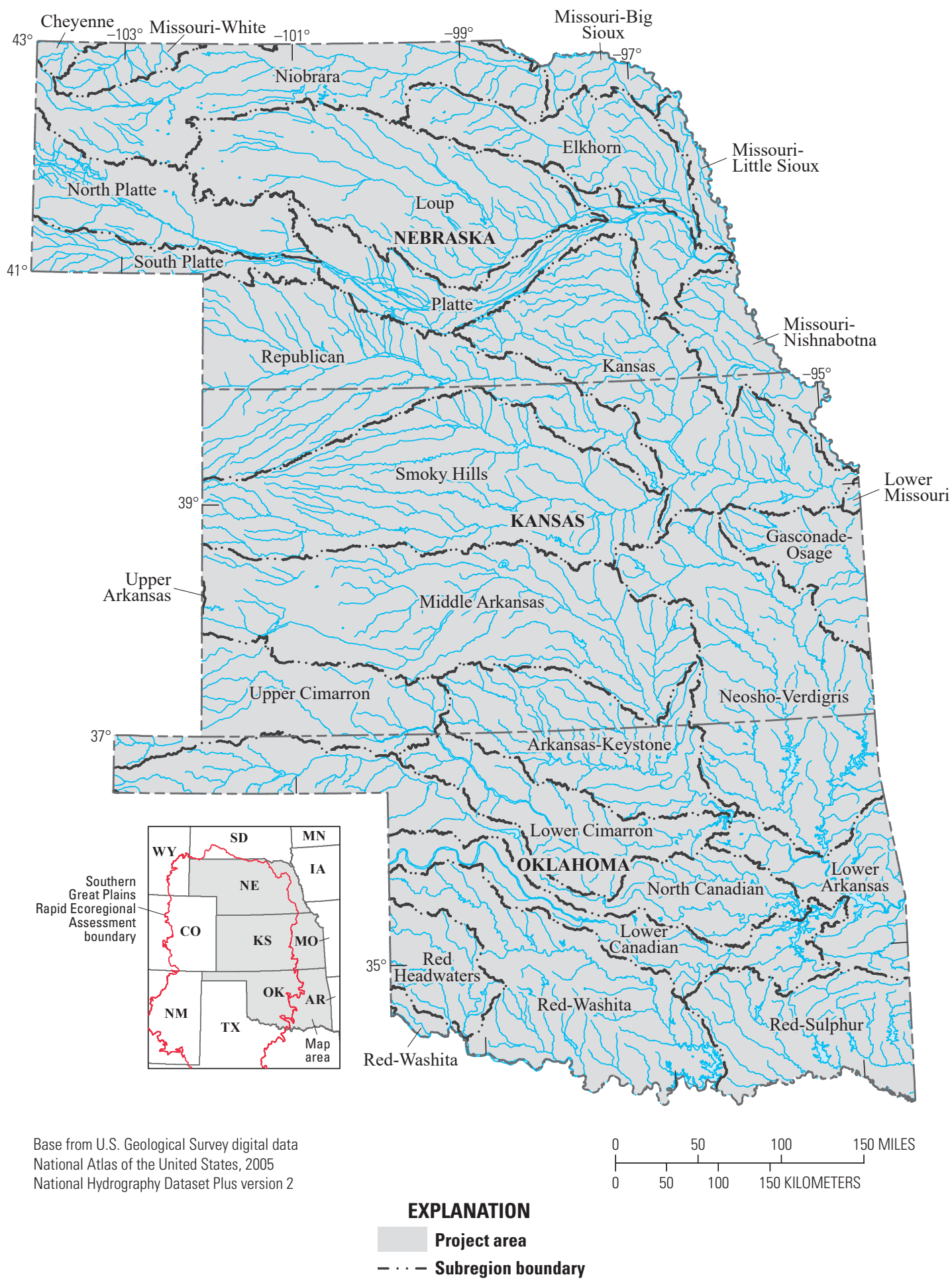

Figure 1. Map showing hydrologic subregions used for summarizing the contemporary distribution of the freshwater mussel assemblage in Nebraska, Kansas, and Oklahoma. The boundary of the Southern Great Plains Rapid Ecoregional Assessment is shown in the map inset. 
potential restoration areas, and providing the broader context for in-depth studies within watersheds, reaches, and subcatchments (Hopkins, 2009; Haag and Williams, 2014; Freshwater Mollusk Conservation Society, 2016; Popejoy and others, 2018).

Although the freshwater mussel assemblage was initially selected as a conservation element for the SGP REA, the spatial extent of species distributions and data limitations ultimately precluded their inclusion in the REA (Reese and others, 2017). The extent of the project area was based on the distribution of mussel species from the Interior Basin faunal group occurring within States intersecting the SGP boundaries (fig. 1). Few species in this faunal group occur within the SGP. This faunal group is more diverse and abundant in the Eastern Temperate Forests ecoregion, adjacent to the SGP, along the eastern extent of Nebraska, Kansas, and Oklahoma where perennial streams and suitable substrates for freshwater mussels are more prevalent (Mather, 2005; Angelo and others, 2009; Hoke, 2011); consequently, the full extents of these States were included in the project area. The freshwater mussel fauna of northern Texas, which is within the SGP, is primarily aligned with the Texas faunal group (Tweedy, 2015). As a result, Texas was excluded from the project area. Because mussels are rare or absent in the remaining States (portions of Colorado, New Mexico, South Dakota, and Wyoming) along the western and northern extent of the SGP, these States were excluded from the project area. In addition, the different spatial extent for the maps of SGP REA change agents and the limited availability of occurrence records precluded the application of standardized REA methodology used for evaluating the effects of change agents on the conservation elements (Reese and others, 2017).

\section{Freshwater Mussel Life History}

Most freshwater mussels require flowing waters, but some species may also occur in ponds, sloughs, lakes, or reservoirs (Haag, 2012). Habitat characteristics that vary among species include streamflow patterns, such as current strength, and substrate types. Adult mussels feed on suspended detritus, algae, bacteria, phytoplankton, zooplankton, and other microorganisms (Haag, 2012). Unionid mussels have a complex life cycle, which requires a host fish for the development and metamorphosis of their parasitic larvae (glochidia) (Haag, 2012). The species of host fish and degree of host specialization vary among mussel species. Methods of host species infection include passive release of glochidia into the water column or more active infection of host fish using specialized attractive structures that lure the host fish. The glochidia attach to the gills of the fish host, where they become encysted and receive nutrients from the host. After several weeks, the glochidia metamorphosize into the juvenile stage, detach from the host, and settle or burrow into streambed sediments. As adults, freshwater mussels are largely sedentary and are thermal conformers (body temperature conforms to ambient water temperature), which makes them vulnerable to fluctuations in water level and temperatures that can exceed their thermal tolerances (Galbraith and others, 2008; Haag and Williams, 2014).

\section{Freshwater Mussel Guilds}

The focal species in the freshwater mussel assemblage represent a broad variety of life history traits, including a range of habitat associations, reproductive characteristics, and thermal tolerances (table 1). Freshwater mussel species with similar life history traits, referred to as a guild, may be useful for evaluating their vulnerability to future environmental change - such as the resistance and resilience of mussel populations to natural and human-modified streamflow dynamics - and for developing management strategies (Galbraith and others, 2010; Vaughn, 2010, 2012; Haag, 2012; Gates and others, 2015; Mitchell and others, 2018). Because species within a guild may respond similarly to environmental variables, the guild approach is sometimes used to make inferences about other species for which data are lacking or otherwise not evaluated (Ries and others, 2016).

Haag (2012) identified three mussel life history strategies - opportunistic, equilibrium, and periodicrelating to their ability to withstand dewatering events. At one end of the spectrum, opportunistic species have high growth rates and early reproduction, which favor rapid colonization, but low tolerance of desiccation from receding waters. At the other end of the spectrum, equilibrium species have long lifespans, which can exceed a century, and lower growth rates. They also have thicker shells and the ability to seal their shells, which provide resistance to desiccation. Periodic species represent an intermediate strategy between the two extremes. Thermal tolerance, associated behavioral responses to desiccation (such as burrowing or tracking of receding waters), and reproductive characteristics (such as brood duration, host specificity and infection mode) can be related to these life history strategies (Galbraith and others, 2010; Allen and Vaughn, 2009; Vaughn 2010, 2012; Gough and others, 2012; Ganser and others, 2015; Gates and others, 2015; Mitchell and others, 2018). Species are considered thermally tolerant if they maintain a good physiological condition at warm temperatures (for example, 35 degrees Celsius $\left[{ }^{\circ} \mathrm{C}\right]$ ), whereas thermally intolerant or sensitive species exhibit poor physiological condition at warm temperatures (Galbraith and others, 2010). The diversity of habitat types and life history traits represented by the freshwater mussel assemblage (table 1) may be useful for representing the vulnerability of other species sharing similar life history traits and regional distribution patterns in the project area. 
Table 1. Habitat association, life history strategy, thermal tolerance, and reproductive characteristics of species in the freshwater mussel assemblage mapped in Nebraska, Kansas, and Oklahoma.

\begin{tabular}{|c|c|c|c|c|c|c|}
\hline \multirow[b]{2}{*}{ Focal species } & \multirow{2}{*}{$\begin{array}{l}\text { General habitat } \\
\text { association1 }\end{array}$} & \multirow{2}{*}{$\begin{array}{l}\text { Life history } \\
\text { strategy² }\end{array}$} & \multirow{2}{*}{$\begin{array}{l}\text { Thermal } \\
\text { tolerance }\end{array}$} & \multicolumn{3}{|c|}{ Reproductive characteristics } \\
\hline & & & & $\begin{array}{c}\text { Brood } \\
\text { duration } 4\end{array}$ & $\begin{array}{c}\text { Host } \\
\text { specificity } 5\end{array}$ & $\begin{array}{l}\text { Host infection } \\
\text { mode }^{6}\end{array}$ \\
\hline Fusconaia flava (Wabash pigtoe) & $\begin{array}{l}\text { Lakes and streams; stable } \\
\text { coarse substrates }\end{array}$ & Equilibrium & Tolerant & Short & Specialist & Passive \\
\hline Lampsilis teres (yellow sandshell) & $\begin{array}{l}\text { Large, low-gradient streams } \\
\text { and shallow lakes; fine } \\
\text { substrates }\end{array}$ & Opportunistic & Intolerant & Long & Specialist & Active \\
\hline Pyganodon grandis (giant floater) & $\begin{array}{l}\text { Lakes and low gradient } \\
\text { streams; fine substrates }\end{array}$ & Opportunistic & Intolerant & Long & Generalist & Passive \\
\hline
\end{tabular}

${ }^{1}$ Grabarkeiwicz and Davis (2008), Haag (2012).

${ }^{2}$ Haag (2012).

${ }^{3}$ Anderson (2005), Galbraith and others (2010), Vaughn (2012), Ganser and others (2015), Gates and others (2015), Mitchell and others (2018), Malish and Woolnough (2019).

${ }^{4}$ Gates and others (2015).

5Vaughn (2012), Gates and others (2015), Tweedy (2015).

${ }^{6}$ Gates and others (2015).

\section{Methods}

We compiled occurrence records for the six focal species from published occurrence records and maps. Occurrence records for the full project area were compiled from the Global Biodiversity Information Facility (GBIF; Global Biodiversity Information Facility, 2017a, b, 2018a, b, c, d). Occurrence records for Kansas were provided by the Kansas Department of Health and Environment (KDHE) for data summarized in Angelo and others (2009). We digitized mapped occurrences of the focal species for Nebraska (Hoke, 2011) and Oklahoma (Mather, 2005). We also compiled a list of all freshwater mussel species confirmed for each State from these source reports and augmented this list with additional species confirmed to occur in eastern Oklahoma (Vaughn and Spooner, 2004; Galbraith and others, 2008).

\section{Assignment of Time Periods}

To provide consistency in the dates of mapped occurrences across State boundaries, we classified survey or source dates into two time periods: historical or contemporary (table 2). Survey dates or compiled sources published prior to
1963 were classified as historical, and survey dates 1970 and later were classified as contemporary. The break point between time periods was based on a temporal gap in the occurrence records between 1960 and 1970 for KDHE data and between 1962 and 1970 for GBIF data (table 2). Large disparities in survey dates summarized by Hoke (2011) and Angelo and others (2009) precluded the use of a narrower date range for the contemporary time period.

Records attributed as archaeological specimens from KDHE were classified as historical. All tabular occurrence records (GBIF, KDHE) lacking dates were classified as unknown. Records attributed as museum vouchers or other published surveys in Hoke (2011) lacked source information and were classified as unknown. All records in Mather (2005) were classified as contemporary (see "Oklahoma" section). Because the most recent occurrence records classified as contemporary were up to several decades old (table 3 ), the resulting distribution maps document the mussel species previously occurring within a given subbasin, but the maps do not confirm current presence. 
Table 2. Data sources, type, geographic extent, and survey time periods used for mapping the distribution of the freshwater mussel assemblage in Nebraska, Kansas, and Oklahoma.

[GBIF, Global Biodiversity Information Facility; KDHE, Kansas Department of Health and Environment; NA, not available]

\begin{tabular}{|c|c|c|c|c|}
\hline \multirow{2}{*}{ Data source } & \multirow{2}{*}{ Data type } & \multirow{2}{*}{ Primary geographic extent } & \multicolumn{2}{|c|}{ Time period } \\
\hline & & & Historical & Contemporary \\
\hline GBIF1 & Compiled survey and museum records & Nebraska, Kansas, and Oklahoma & 1909-1960 & 1970-2017 \\
\hline Hoke $(2011)^{2}$ & Compiled survey and museum records & Nebraska & Unknown & Unknown \\
\hline $\mathrm{KDHE}^{1}$ & Surveys & Kansas & NA & $1990-2006$ \\
\hline Mather $(2005)^{4}$ & Compiled survey and museum records & Oklahoma & NA & Unknown \\
\hline
\end{tabular}

1Occurrence records with dates not specified were classified as unknown.

2Dates of occurrence records from compiled museum vouchers and published surveys could not be determined and were classified as unknown.

3Publication years of compiled surveys prior to 1970 or archaeological specimens were classified as historical.

4Dates of all mapped occurrence records were not defined but were assumed to be 1970 or later and were used to classify occurrences as contemporary.

Table 3. Number of occurrence records used for mapping the distribution of focal species in the freshwater mussel assemblage in Nebraska, Kansas, and Oklahoma.

[KDHE, Kansas Department of Health and Environment; GBIF, Global Biodiversity Information Facility]

\begin{tabular}{|c|c|c|c|c|c|}
\hline \multirow{2}{*}{ Focal species } & \multicolumn{5}{|c|}{ Number of records by data source 1} \\
\hline & KDHE & GBIF & Hoke ${ }^{2}$ & Mather2 & Total \\
\hline Amblema plicata (threeridge) & 1,193 & 89 & 40 & 60 & 1,382 \\
\hline Fusconaia flava (Wabash pigtoe) & 927 & 68 & 44 & 52 & 1,091 \\
\hline Lampsilis cardium (plain pocketbook) & 652 & 18 & 56 & 48 & 774 \\
\hline Lampsilis teres (yellow sandshell) & 721 & 45 & 31 & 69 & 866 \\
\hline Pyganodon grandis (giant floater) & 1,197 & 75 & 208 & 112 & 1,592 \\
\hline Uniomerus tetralasmus (pondhorn) & 704 & 41 & 70 & 52 & 867 \\
\hline Total of all focal species & 5,394 & 336 & 449 & 393 & 6,572 \\
\hline
\end{tabular}

${ }^{1}$ Mather (2005); Kansas Department of Health and Environment records were mapped in Angelo and others (2009); Hoke (2011); Global Biodiversity Information Facility (2017a, b, 2018a, b, c, d)

2Record number reflects the number of digitized locations from published maps.

\section{Overview of State-Level Surveys}

The published occurrence records were compiled from qualitative surveys, reports, and museum records (table 2). The number, dates, and duration of surveys varied considerably among data sources (tables 2 and 3). Although there can be limitations associated with nonrandom and qualitative surveys, especially at local scales, such information can be useful for mapping the distributions of freshwater mussels at broad spatial extents (Obermeyer, 1998).

\section{Nebraska}

Hoke (2011) documented the occurrence of 31 native freshwater mussel species in Nebraska from occurrence records at 680 sites surveyed between 1972 and 2000 as well as compiled museum vouchers and published survey records. The survey sites were selected from accessible locations, typically road crossings, and were broadly distributed across Nebraska (Hoke, 2011, figs. 3 and 4 denote sampling locations). Mussels were detected at 58 percent of survey locations. The surveys confirmed the presence of 24 extant species at the time of the surveys, with 1 additional species (Villosa lienosa [little spectaclecase]) mapped only from museum vouchers 
(table 4). Six additional species (Lasmigona compressa [creek heelsplitter], Ligumia recta [black sandshell], Obovaria olivaria [hickorynut], Ortmanniana ligamentina [mucket], Pleurobema clava [clubshell], and Potamilus purpuratus [bleufer]) are presumed to be extirpated in Nebraska because only relict shells were observed during surveys (Hoke, 2011).

\section{Kansas}

The KDHE conducted comprehensive mussel surveys between 1990 and 2007 at 2,210 sites (Angelo and others, 2009, fig. 2 denotes sampling locations). The sampling locations were broadly distributed across Kansas and focused on perennial and intermittent streams as well as publicly owned lakes and wetlands. Surveys were repeated twice within the survey period for 128 reaches, and an additional 98 (randomly selected) smaller wadeable reaches were surveyed in 2006 and 2007 (Angelo and others, 2009). Live mussels, unweathered shells, or both were detected at 54 percent of survey locations indicating extant populations. At 10 percent of survey locations, the lack of live specimens and the presence of only weathered or subfossil (heavily worn) mussel shells indicate the potential for local extirpation of a species. In addition to the surveys conducted by the KDHE, historical records or contemporary survey records were compiled from other sources; record types (museum voucher or archaeological specimen), date of publication (prior to 1970 ), or both were used to classify these ancillary records as historical (Angelo and others, 2009).

These extensive surveys over 18 years documented the presence of live individuals of 42 mussel species (table 4). One additional species (Obovaria olivaria) was represented only by weathered and subfossil shells and may have been extirpated (Angelo and others, 2009). Four additional species previously confirmed in Kansas are presumed to have been extirpated (Alasmidonta viridis [slippershell mussel], Epioblasma triquetra [snuffbox], Lasmigona compressa, and Quadrula fragosa [winged mapleleaf mussel]; table 4). An additional five species were reported in Kansas but lack museum vouchers; these species (Lampsilis abrupta [pink mucket], Lampsilis satura [sandbank pocketbook], Leptodea leptodon [scaleshell], Plethobasus cyphyus [sheepnose], and Reginaia ebena [ebonyshell]) may have been extirpated.

\section{Oklahoma}

Mather (2005) mapped the distribution of 43 extant mussel species in Oklahoma - as well as 2 species (Cyprogenia aberti [western fanshell] and Ligumia recta) that are presumed to have been extirpated - based on a compilation of occurrence records (table 4). Vaughn and Spooner (2004) and Galbraith and others (2008) documented the presence of five additional species (Lampsilis satura, Pleurobema rubrum [pyramid pigtoe], Quadrula fragosa, Q. nobilis [gulf mapleleaf], and Toxolasma texasiense [Texas lilliput]) in Oklahoma. Three species (Obovaria olivaria, Potamilus amphichaenus [Texas heelsplitter], and Toxolasma lividum [purple lilliput]) were previously reported in Oklahoma and could not be verified but were considered potentially present (Mather, 2005).

The approximate location of each mapped record was based on descriptions of physical sites (Mather, 2005). Because the data sources for the mapped records were not provided, the date of these records could not be ascertained. We assumed that the distribution maps primarily corresponded to the contemporary time period (1970 or later) based on a reference to "collections, particularly during the past 20 years" and the "current list" presented in comparison to publications from 1925, 1971, 1998, 2003, and in press (Mather, 2005, see app. A). However, it is possible that some records used to map the contemporary distribution predated 1970 . The contemporary occurrences in 66 percent of the subbasins documented by Mather (2005) were confirmed by contemporary occurrence records from GBIF, KDHE, or both (Fancher and Carr, 2021).

\section{The Freshwater Mussel Fauna}

The native freshwater mussel fauna for the project area was compiled from all extant and potentially extirpated species with documented occurrences in at least one of the three States. To assess the relative rarity of the mussel species within the project area, we classified the spatial extent of all species with mapped distributions - as well as four unmapped species listed as extirpated - by State using the following four categories: (1) absent (no documented occurrences), (2) possibly extirpated (museum vouchers, but no living specimens in contemporary surveys), (3) isolated or narrowly distributed populations, and (4) widely distributed (present in more than one-quarter of the State). The conservation status of each mussel species was based on State wildlife action plans (Rohweder, 2015; Oklahoma Department of Wildlife Conservation, 2016; Schneider and others, 2018), and at the national level using NatureServe Conservation Status Ranks (NatureServe, 2020) and species listed as federally threatened or endangered (U.S. Fish and Wildlife Service, 2020). Most of the native mussel species occurring within the project area are widely distributed throughout the Mississippi Basin (Williams and others, 1993) and the western periphery of the range for many of these species occurs along the eastern side of the project area.

\section{The Freshwater Mussel Assemblage}

Published maps for the freshwater mussel assemblage for Nebraska in Hoke (2011) and for Oklahoma in Mather (2005) were georeferenced, and mapped locations were digitized onscreen and saved as shapefiles (Fancher and Carr, 2021). Map information on data sources (living or subfossil) provided in Hoke (2011) was captured as attributes. Tabular data provided by KDHE and GBIF were standardized to a common format, and all records lacking location information were dropped. Tabular data were converted to shapefiles. All geoprocessing was completed using ArcMap 10.3.1 (Esri, 2014). 
Table 4. Distribution classes and conservation status for extant and extirpated freshwater mussels mapped in Nebraska, Kansas, and Oklahoma.

[All scientific names are from ITIS (2020). Distributions were classified using published distribution maps and summarized information for each species in Nebraska (Hoke, 2011), Kansas (Angelo and others, 2009), and Oklahoma (Mather, 2005). Species included in the freshwater mussel assemblage are shaded. Distribution class_-A, absent; X, possibly extirpated; I, isolated or narrowly distributed populations; W, widely distributed]

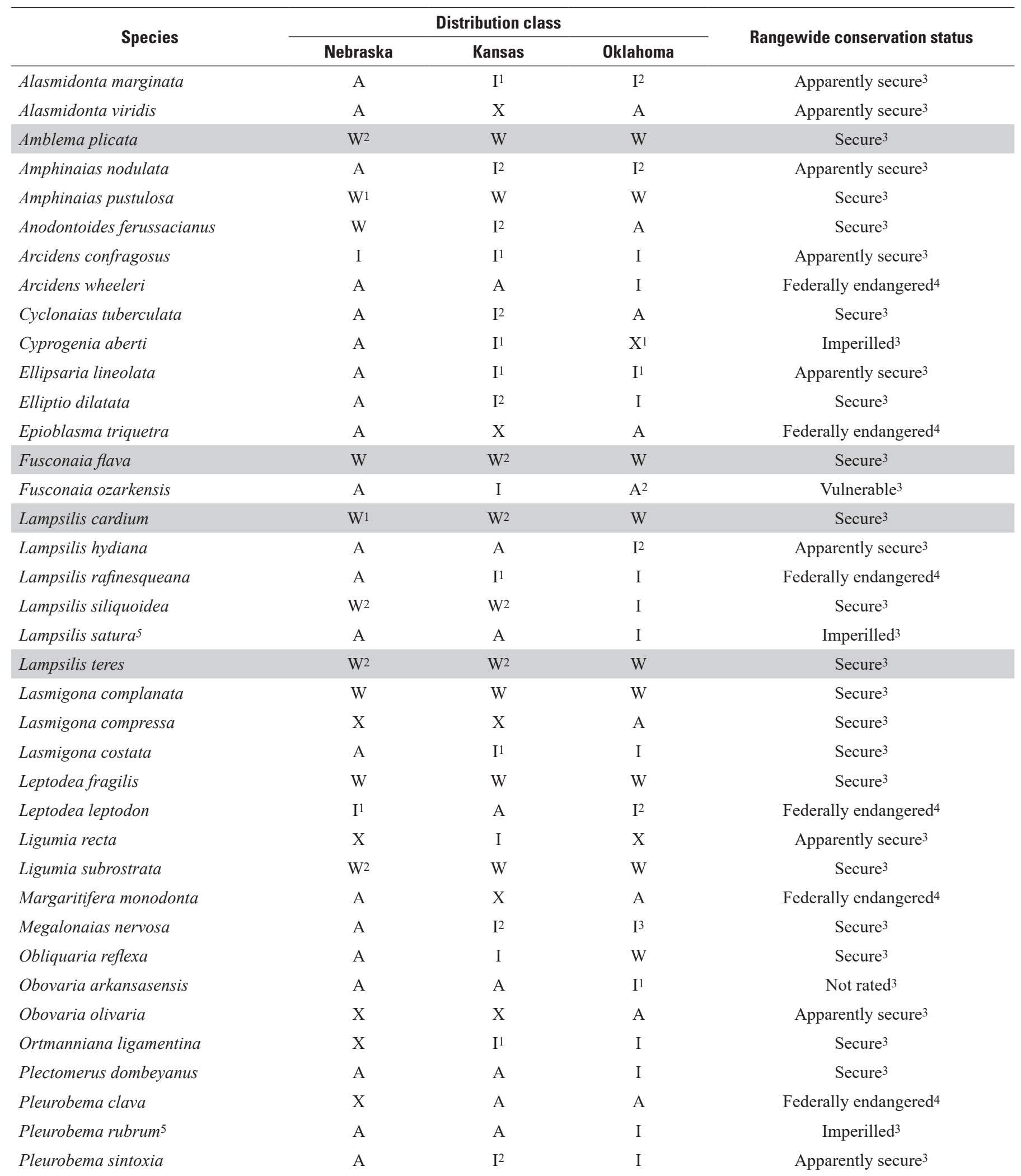


Table 4. Distribution classes and conservation status for extant and extirpated freshwater mussels mapped in Nebraska, Kansas, and Oklahoma.-Continued

[All scientific names are from ITIS (2020). Distributions were classified using published distribution maps and summarized information for each species in Nebraska (Hoke, 2011), Kansas (Angelo and others, 2009), and Oklahoma (Mather, 2005). Species included in the freshwater mussel assemblage are shaded. Distribution class-A, absent; X, possibly extirpated; I, isolated or narrowly distributed populations; W, widely distributed]

\begin{tabular}{|c|c|c|c|c|}
\hline \multirow{2}{*}{ Species } & \multicolumn{3}{|c|}{ Distribution class } & \multirow{2}{*}{ Rangewide conservation status } \\
\hline & Nebraska & Kansas & Oklahoma & \\
\hline Potamilus alatus & I & $\mathrm{I}^{2}$ & A & Secure $^{3}$ \\
\hline Potamilus ohiensis & $\mathrm{W}$ & $\mathrm{W}$ & W & Secure $^{3}$ \\
\hline Potamilus purpuratus & $\mathrm{X}$ & $\mathrm{W}^{2}$ & $\mathrm{~W}$ & Secure $^{3}$ \\
\hline Ptychobranchus occidentalis & A & $\mathrm{I}^{1}$ & I & Vulnerable 3 \\
\hline Pyganodon grandis & W & W & W & Secure $^{3}$ \\
\hline Quadrula apiculata & A & A & $\mathrm{W}$ & Secure $^{3}$ \\
\hline Quadrula fragosa ${ }^{5}$ & A & $\mathrm{X}$ & $\mathrm{I}^{1}$ & Federally endangered ${ }^{4}$ \\
\hline Quadrula nobilis 6 & A & A & I & Apparently secure 3 \\
\hline Quadrula quadrula & $\mathrm{W}$ & $\mathrm{W}$ & $\mathrm{W}$ & Secure $^{3}$ \\
\hline Strophitus undulatus & W & $\mathrm{W}^{2}$ & I & Secure $^{3}$ \\
\hline Theliderma cylindrica & A & $\mathrm{I}^{1}$ & $\mathrm{I}^{2}$ & Federally threatened ${ }^{4}$ \\
\hline Theliderma metanevra & A & I & I & Apparently secure 3 \\
\hline Toxolasma parvum & I & $\mathrm{W}^{2}$ & $\mathrm{~W}$ & Secure $^{3}$ \\
\hline Toxolasma texasiense ${ }^{5}$ & A & A & $\mathrm{I}^{2}$ & Apparently secure 3 \\
\hline Tritogonia verrucosa & $\mathrm{I}^{1}$ & W & $\mathrm{W}$ & Apparently secure ${ }^{3}$ \\
\hline Truncilla donaciformis & I & $I^{2}$ & I & Secure $^{3}$ \\
\hline Truncilla truncata & I & $I^{2}$ & I & Secure $^{3}$ \\
\hline Uniomerus tetralasmus & W & $\mathrm{W}^{2}$ & $\mathrm{~W}$ & Secure $^{3}$ \\
\hline Utterbackia imbecillis & W & W & $\mathrm{W}$ & Secure $^{3}$ \\
\hline Utterbackia suborbiculata & $\mathrm{I}^{1}$ & $\mathrm{I}^{1}$ & I & Secure $^{3}$ \\
\hline Venustaconcha ellipsiformis & A & $\mathrm{I}^{1}$ & A & Apparently secure ${ }^{3}$ \\
\hline Villosa iris & A & A & I & Secure $^{3}$ \\
\hline Villosa lienosa & $\mathrm{X}$ & A & I & Secure $^{3}$ \\
\hline
\end{tabular}

1Tier 1 (highest priority species of greatest conservation need in State wildlife action plans; Rohweder, 2015; Oklahoma Department of Wildlife Conservation, 2016; Schneider and others, 2018).

2Tier 2 (second priority species of greatest conservation need in State wildlife action plans; Rohweder, 2015; Oklahoma Department of Wildlife Conservation, 2016; Schneider and others, 2018).

${ }^{3}$ NatureServe (2020). Imperiled (at high risk of extinction), vulnerable (at moderate risk of extinction), apparently secure (at fairly low risk of extinction), and secure (at very low risk of extinction).

4 U.S. Fish and Wildlife Service (2020).

${ }^{5}$ Galbraith and others (2008).

6Vaughn and Spooner (2004).

After eliminating records located outside of the project-area boundary, the remaining 6,572 records were used for mapping the distribution of species in the freshwater mussel assemblage by subbasin (the minimum resolution permitted for publishing the source data) and by subregion. The KDHE provided 82 percent of all records (table 3), most of which were concentrated in eastern Kansas. However, location data compiled from published maps (Mather, 2005;
Hoke, 2011) may represent multiple records from a location, so sample sizes for these data sources reflect the number of mapped locations (table 3). For each focal species, we summarized the occurrences by time period in each subbasin (Fancher and Carr, 2021) and used this information to map the contemporary, as well as historical-only (contemporary occurrence records lacking), occurrences by subbasin (figs. 2, $3,4,5,6$, and 7). 


\section{Results}

\section{Conservation Status and Distribution Patterns of the Freshwater Mussel Fauna}

The freshwater mussel fauna for the project area included 61 native extant or apparently extirpated species that were documented to occur in at least one State (table 4), as well as 2 introduced species: (Corbicula fluminea [Asian clam] and Dreissena polymorpha [zebra mussel]) (Vaughn and Spooner, 2004; Mather, 2005; Galbraith and others, 2008; Angelo and others, 2009; Hoke, 2011). Of the 61 documented native species, there were 24 extant species in Nebraska, 42 in Kansas, and 48 in Oklahoma. Many of the extant species we classified as having isolated populations were represented by only a few contemporary occurrence records and may have subsequently become extirpated (Angelo and others, 2009). Twelve of the mussel species mapped in the project area have apparently been extirpated from at least one State (table 4). Cyprogenia aberti, Ligumia recta, Ortmanniana ligamentina, Potamilus purpuratus, Quadrula fragosa, and Villosa lienosa have been potentially extirpated in one State but remain present elsewhere in the project area. Alasmidonta viridis, Epioblasma triquetra, Lasmigona compressa, Margaritifera monodonta (spectaclecase), Obovaria olivaria, and Pleurobema clava have apparently been extirpated from the project area. Seven additional species (Lampsilis abrupta, L. reeveiana [Arkansas broken-ray], Plethobasus cyphyus, Potamilus amphichaenus, Reginaia ebena, Simpsonaias ambigua [salamander mussel], and Toxolasma lividum) were listed as possibly extirpated on the basis of their presence in neighboring States (Mather, 2005; Hoke, 2011) but were not included in table 4 because there were no documented occurrences of these species within the project area.

Eight of the mussel species in the project area (including three apparently extirpated species) are listed as federally threatened or endangered (U.S. Fish and Wildlife Service, 2020), and an additional five species are considered imperiled (at high risk of extinction) or vulnerable (at moderate risk of extinction) across their range (NatureServe, 2020). At a national level, 48 species in the project area are not considered at risk (as indicated by national rankings: apparently secure - at fairly low risk of extinction; secure-at very low risk of extinction) or were "not rated" (NatureServe, 2020); however, 63 percent of these 48 species are of local conservation concern in at least one State (Tier 1 - highest priority or Tier 2 - second highest priority, species of greatest conservation need in State wildlife action plans), including 4 of the species in the mussel assemblage (table 4; Rohweder, 2015; Oklahoma Department of Wildlife Conservation, 2016; Schneider and others, 2018).

\section{Distribution of the Freshwater Mussel Assemblage}

All species in the freshwater mussel assemblage were widely distributed in all three States (table 4). The core contemporary distribution for all species in the freshwater mussel assemblage is concentrated along the eastern side of each State (figs. 2, 3, 4, 5, 6, and 7). Lampsilis cardium had the most limited distribution, with occurrences in 32 percent of subbasins and 57 percent of subregions (fig. 4, table 5). The distribution of Amblema plicata generally coincides with that of Fusconaia flava; both species were documented in 33 percent of subbasins and 61 percent of subregions (figs. 2 and 3, table 5). Lampsilis teres was documented in 42 percent of subbasins and 71 percent of subregions (fig. 5, table 5). Uniomerus tetralasmus was widely distributed across Kansas and large portions of Nebraska and Oklahoma, covering 59 percent of subbasins and 75 percent of subregions (fig. 7 , table 5). Pyganodon grandis was the most widely distributed of all the species, occurring in 73 percent of subbasins and 93 percent of subregions (fig. 6 , table 5). The full complement of the six focal species in the mussel assemblage was documented in 19 percent of subbasins and 57 percent of subregions (table 5). Because of differences in methods and sampling intensity (table 5), the number of species by subbasin or subregions cannot be directly compared across State boundaries.

Mapped historical records for Nebraska and Oklahoma were limited, and most subbasins with only historical mussel occurrences were in Kansas. The number of subbasins with only historical occurrences ranged between 1 and 7 among species (figs. 2, 3, 4, 5, 6, and 7). There is little spatial congruence among species for subbasins with only historical occurrences. However, the historical-only subbasins are predominantly along the western edge of the distributions, indicating the potential for range contraction even for common and widespread species such as Pyganodon grandis and Uniomerus tetralasmus. 
Table 5. Contemporary occurrence records for the freshwater mussel assemblage by subregions and subbasins in Nebraska, Kansas, and Oklahoma (see table 2 for dates of contemporary surveys).

[HUC, hydrologic unit code for subregions; AMPL, Amblema plicata; FUFL, Fusconaia flava; LACA, Lampsilis cardium; LATE, L. teres; PYGR, Pyganodon grandis; UNTE, Uniomerus tetralasmus]

\begin{tabular}{|c|c|c|c|c|c|c|c|c|c|}
\hline \multicolumn{3}{|c|}{ Subregion } & \multicolumn{6}{|c|}{$\begin{array}{l}\text { Number of subbasins with occurrence records } \\
\text { (by species) }\end{array}$} & \multirow{2}{*}{$\begin{array}{l}\text { Number of } \\
\text { records }\end{array}$} \\
\hline HUC1 & Name & $\begin{array}{c}\text { Number } \\
\text { of subbasins }\end{array}$ & AMPL & FUFL & LACA & LATE & PYGR & UNTE & \\
\hline 1012 & Cheyenne & 2 & 0 & 0 & 0 & 0 & 0 & 0 & 0 \\
\hline 1014 & Missouri-White & 3 & 0 & 0 & 0 & 0 & 1 & 0 & 1 \\
\hline 1015 & Niobrara & 7 & 0 & 0 & 0 & 0 & 3 & 0 & 4 \\
\hline 1018 & North Platte & 4 & 0 & 0 & 0 & 0 & 2 & 0 & 8 \\
\hline 1019 & South Platte & 5 & 0 & 0 & 0 & 0 & 1 & 0 & 3 \\
\hline 1020 & Platte & 6 & 1 & 1 & 2 & 2 & 5 & 3 & 94 \\
\hline 1021 & Loup & 10 & 0 & 0 & 0 & 0 & 6 & 1 & 18 \\
\hline 1022 & Elkhorn & 4 & 2 & 2 & 4 & 2 & 4 & 2 & 81 \\
\hline 1026 & Smoky Hill & 15 & 2 & 5 & 4 & 8 & 15 & 15 & 235 \\
\hline 1027 & Kansas & 11 & 7 & 7 & 9 & 7 & 11 & 11 & 1,075 \\
\hline 1029 & Gasconade-Osage & 5 & 4 & 4 & 4 & 4 & 4 & 4 & 763 \\
\hline 1030 & Lower Missouri & 1 & 1 & 1 & 1 & 1 & 1 & 1 & 177 \\
\hline 1102 & Upper Arkansas & 1 & 0 & 0 & 0 & 0 & 0 & 0 & 0 \\
\hline 1103 & Middle Arkansas & 18 & 6 & 5 & 4 & 11 & 15 & 16 & 616 \\
\hline 1104 & Upper Cimarron & 8 & 0 & 0 & 0 & 0 & 4 & 2 & 32 \\
\hline 1105 & Lower Cimarron & 3 & 0 & 0 & 0 & 1 & 3 & 2 & 9 \\
\hline 1106 & Arkansas-Keystone & 6 & 4 & 3 & 3 & 3 & 6 & 5 & 224 \\
\hline 1107 & Neosho-Verdigris & 16 & 15 & 15 & 14 & 14 & 15 & 13 & 2,312 \\
\hline \multicolumn{2}{|c|}{ Total number } & 201 & 66 & 66 & 65 & 84 & 147 & 119 & 6,572 \\
\hline
\end{tabular}

1The first two digits of the hydrologic unit code (HUC) denote the Missouri Region (10) or the Arkansas-White-Red Region (11). 


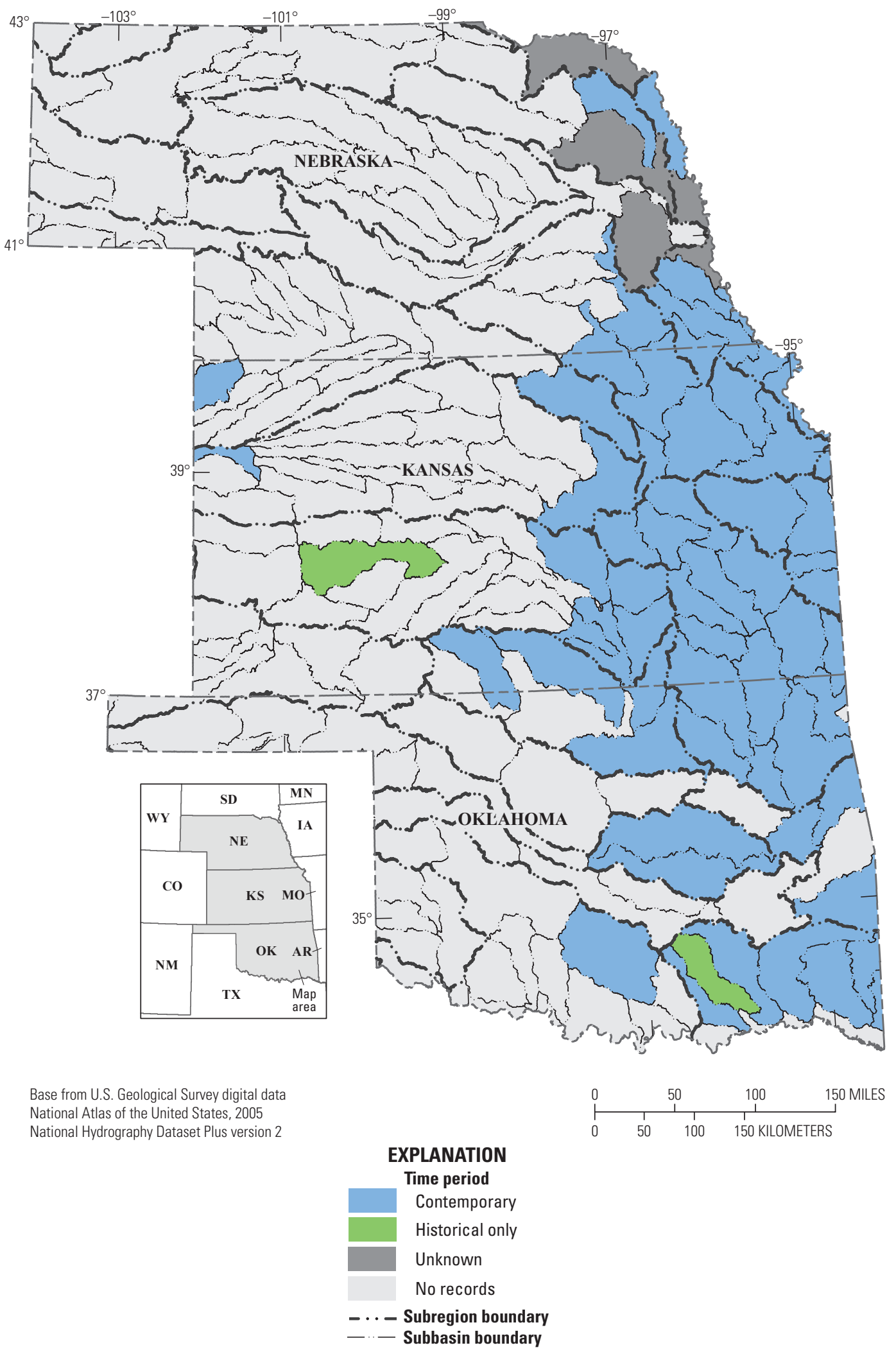

Figure 2. Map showing the distribution of Amblema plicata (threeridge) in Nebraska, Kansas, and Oklahoma. 


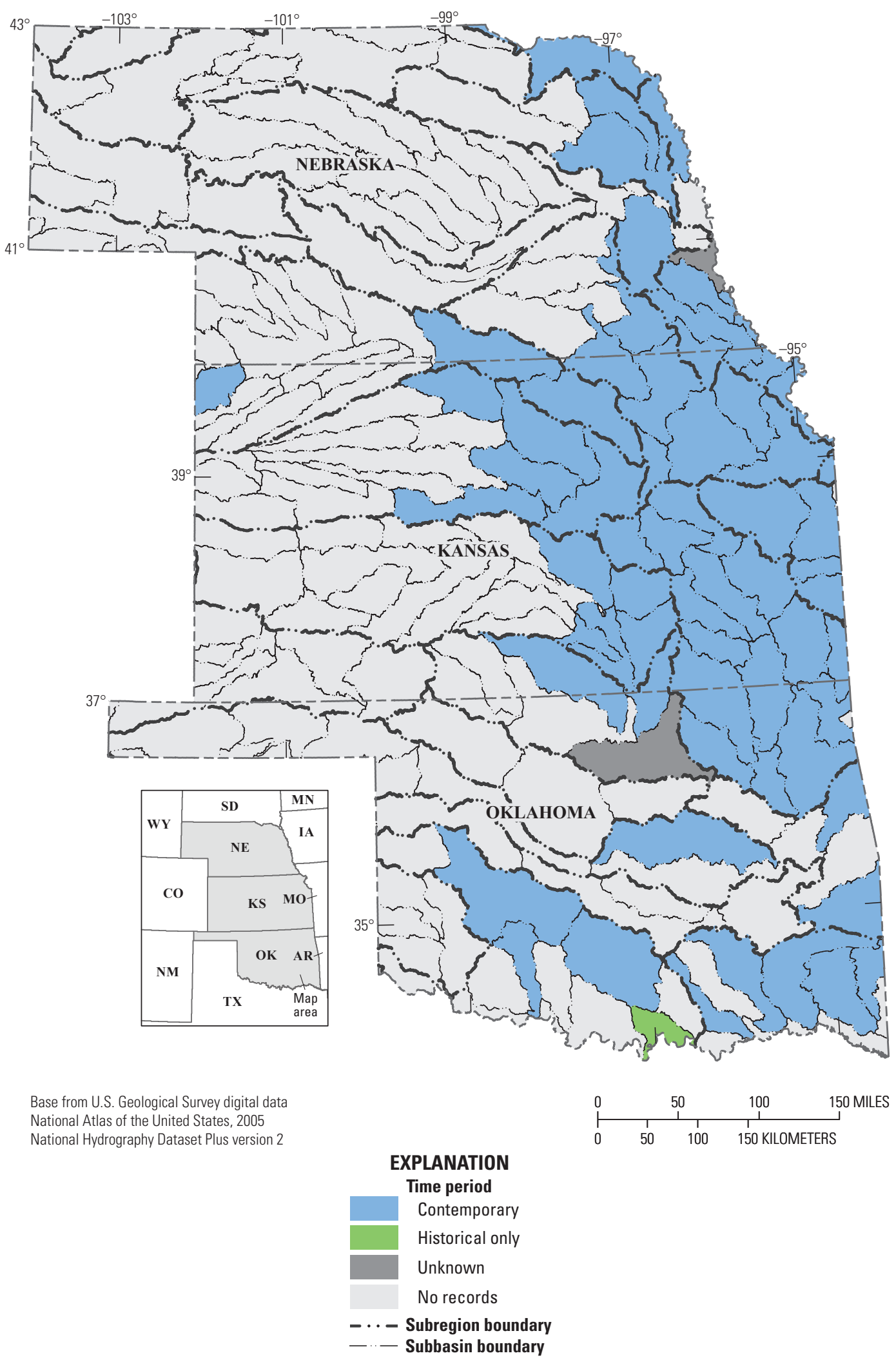

Figure 3. Map showing the distribution of Fusconaia flava (Wabash pigtoe) in Nebraska, Kansas, and Oklahoma. 


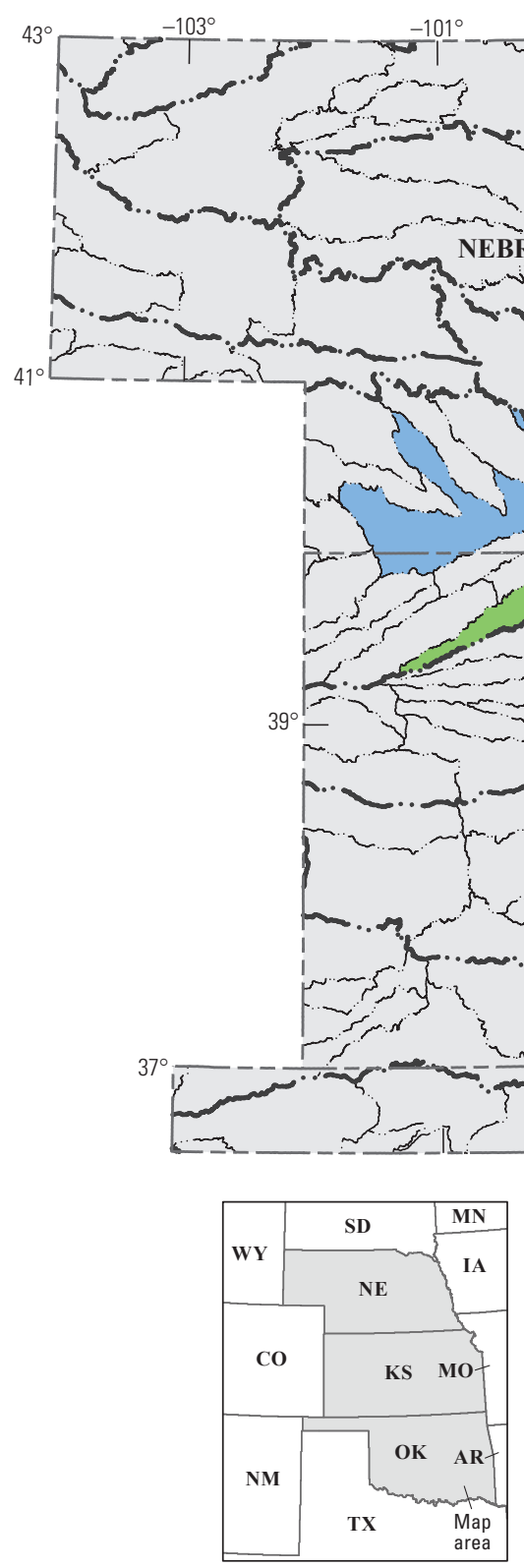

Base from U.S. Geological Survey digital data National Atlas of the United States, 2005 National Hydrography Dataset Plus version 2

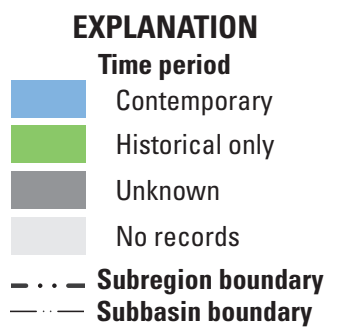

Figure 4. Map showing the distribution of Lampsilis cardium (plain pocketbook) in Nebraska, Kansas, and Oklahoma. 


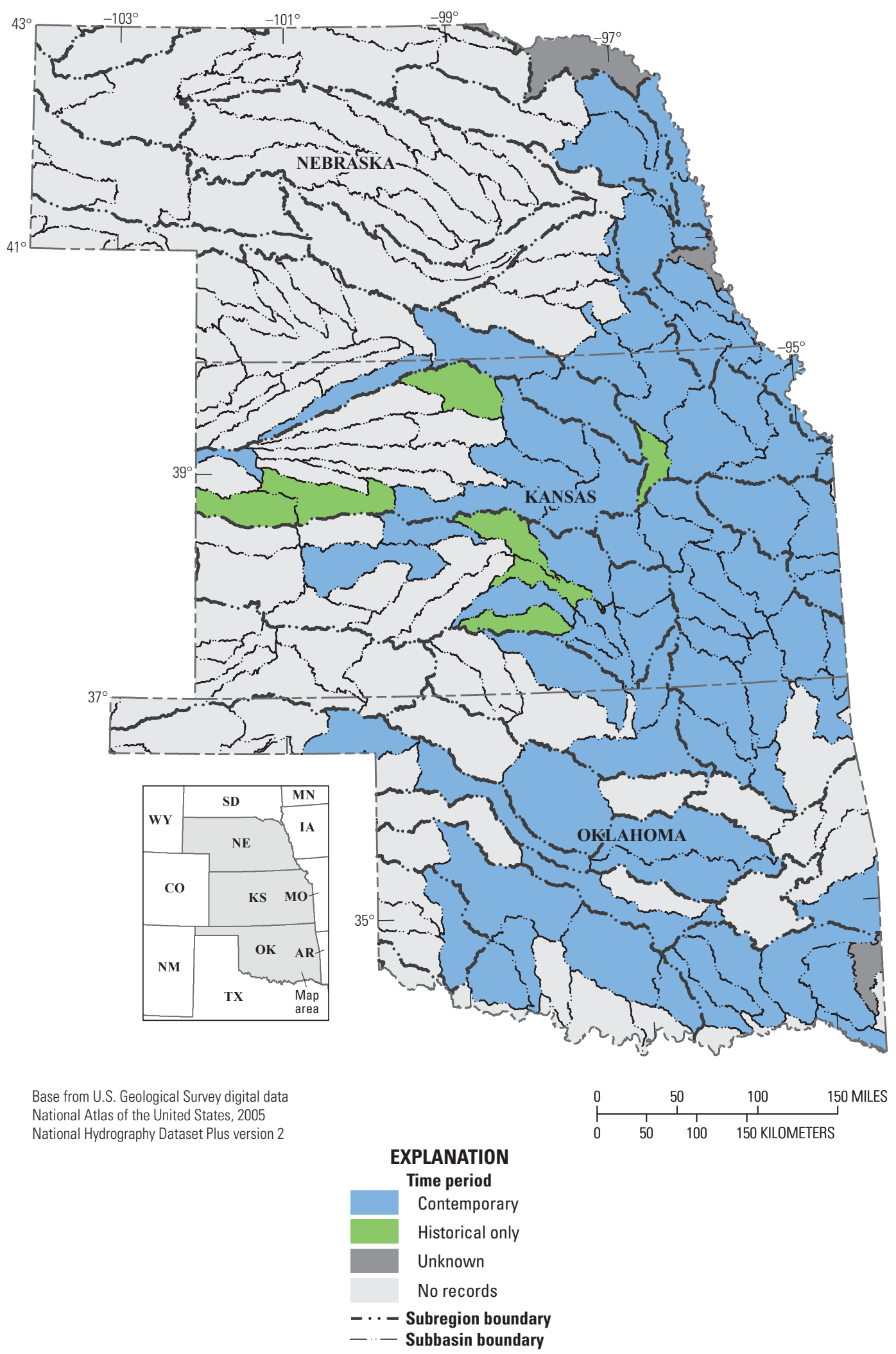

Figure 5. Map showing the distribution of Lampsilis teres (yellow sandshell) in Nebraska, Kansas, and Oklahoma. 


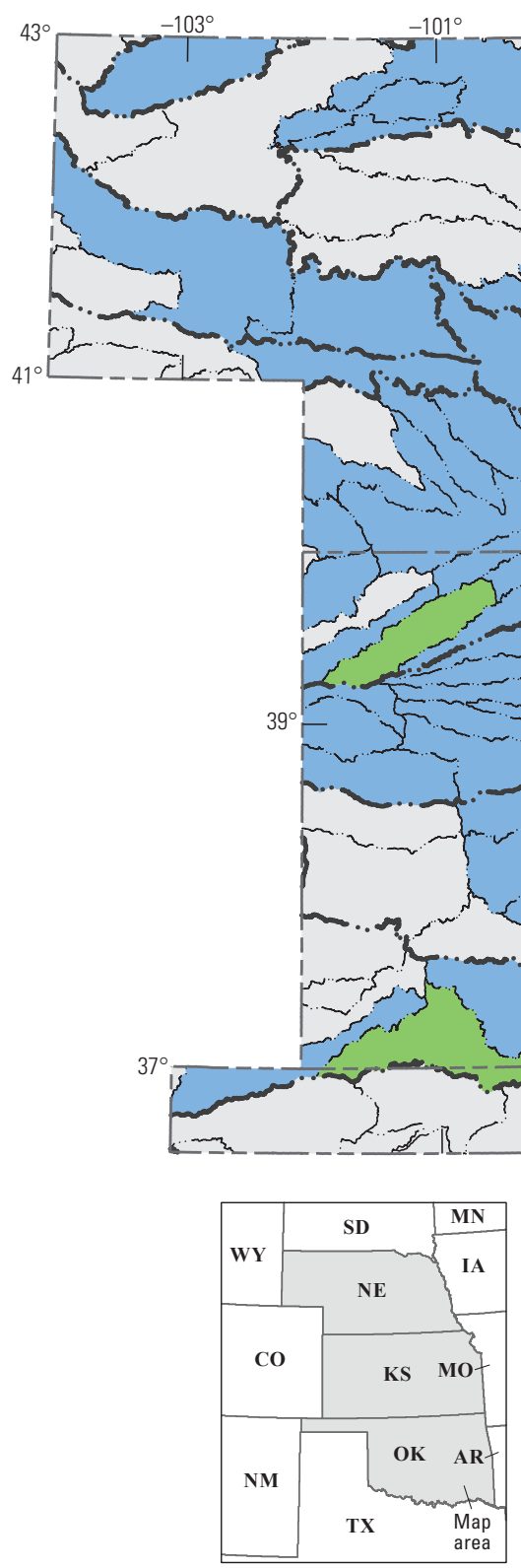

Base from U.S. Geological Survey digital data

National Atlas of the United States, 2005

National Hydrography Dataset Plus version 2

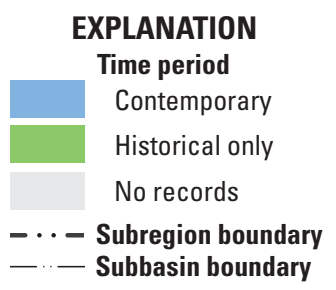

Figure 6. Map showing the distribution of Pyganodon grandis (giant floater) in Nebraska, Kansas, and Oklahoma. 


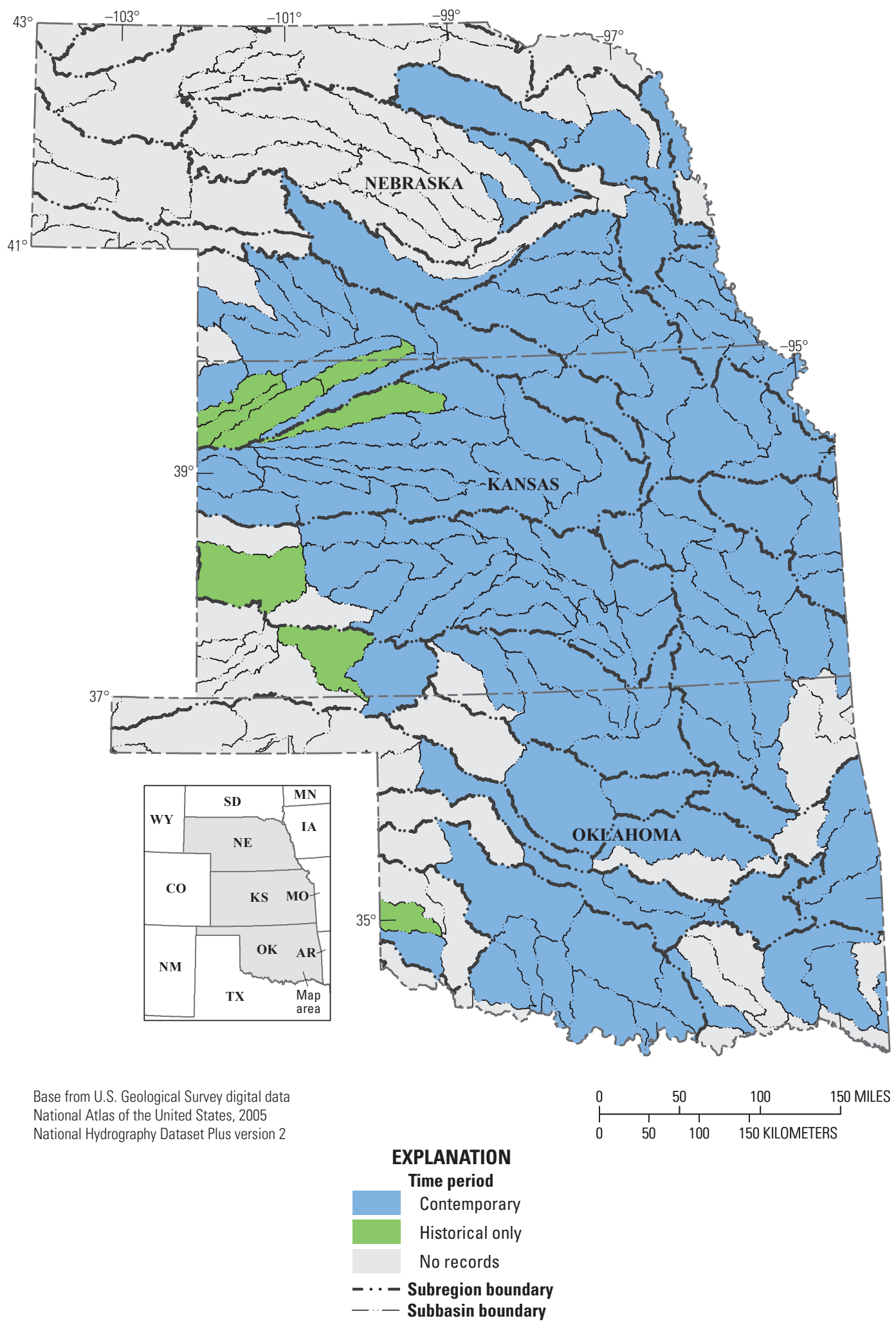

Figure 7. Map showing the distribution of Uniomerus tetralasmus (pondhorn) in Nebraska, Kansas, and Oklahoma. 


\section{Discussion}

The contemporary distribution maps (figs. 2, 3, 4, 5, 6, and 7) are graphical representations of the associated data release (Fancher and Carr, 2021) for the six focal species in the freshwater mussel assemblage. These maps represent the best publicly available geospatial data on the freshwater mussel assemblage in Nebraska, Kansas, and Oklahoma, which are typically mapped at the State - rather than subbasin or subregion-level. This multiscale, spatially explicit dataset can provide both baseline information and the larger context for more detailed watershed- or catchment-level studies (Haag, 2012; Freshwater Mollusk Conservation Society, 2016; Popejoy and others, 2018). Because the populations of many freshwater mussel species are declining in the project area (Galbraith and others, 2008; Angelo and others, 2009), the contemporary distribution maps, which are based on surveys that may be many decades old, could include subbasins in which populations have become locally extirpated. Many mussel species are long lived, however, and it is recommended that mussel surveys be conducted at least 15 years apart (Galbraith and others, 2010). Consequently, surveys conducted after 2005 are within the recommended sampling frequency and may be similar to current distributions, but even older surveys may still reflect the current distribution for longer-lived equilibrium species (table 1). The documented historical distributions for each species largely overlap their contemporary distributions except for a small number of subbasins that had only historical records of occurrence (figs. 2, $3,4,5,6$, and 7).

The 6 focal species of the freshwater mussel assemblage possess a variety of life history traits, including a range of thermal tolerances (table 1); thus, the freshwater mussel assemblage collectively may be representative of conservation and management issues also relevant to the other 15 species distributed widely in at least one State in the project area (table 4; Gates and others, 2015). The degree to which the focal species are representative of other mussel species within the same guild depends, in part, on the type and scale of ecological processes evaluated (Caro, 2010; Ries and others, 2016).

Water management and episodic events can locally affect populations of mussel species differently depending on their life history traits, such as thermal tolerance. For example, the effects of a severe drought downstream of impoundments in southeastern Oklahoma were magnified by water management, which led to a shift in dominance and abundance of thermally tolerant mussel species (including species in the mussel assemblage) in the Kiamichi River. In contrast, populations of all mussel species were more stable in the Little River, where water releases helped to maintain water levels downstream of the impoundment (Allen and others, 2013). Over longer time scales, there is also evidence that an increase in nutrient levels and eutrophication has led to increased body size for some populations of Amblema plicata, a thermally tolerant species that is also relatively tolerant of altered flows and nutrient loads (Fritts and others, 2017). In some areas, improved water-management activities may be helping to increase the abundance of species that vary in life history strategies (table 1). For example, between 1991 and 2003, populations of Fusconaia flava (an equilibrium species) and Lampsilis teres (an opportunistic species) both increased in the Verdigris River in Kansas, presumably in response to minimum flow releases that helped to maintain downstream water levels, lowered flow rates during peak reservoir discharges, of both (Miller and Lynott, 2006).

Although range contractions and population declines have been reported for even the most common species in the project area, approximately 80 percent of the 61 native species (extant or extirpated) known to occur in the project area are nevertheless considered secure nationwide (table 4). In comparison, only 40 percent of all freshwater mussel species or subspecies in the United States are apparently secure (NatureServe, 2020). All species in the mussel assemblage are considered secure, although the ranges of five species have been reported to be contracting in the project area, and four species are of concern at the State level (table 4). In Kansas, weathered shells or subfossils but (no live specimens) of Amblema plicata, Fusconaia flava, Lampsilis cardium, and Lampsilis teres were found in many subbasins along the western periphery of their ranges (figs. 2, 3, 4, and 5; Angelo and others, 2009, figs. A3, A11, A13, and A16), indicating the potential for local extirpations and range contractions. Only Pyganodon grandis populations appear to be stable or increasing in the project area (Angelo and others, 2009; Hoke 2011). Local extirpations may be more likely along the edge of distributions where mussels reach the limit of their ecological tolerances (Angelo and others, 2009; Hoke, 2011). The most widespread species within the project area, Pyganodon grandis and Uniomerus tetralasmus (figs. 6 and 7), are more tolerant of harsh conditions (such as low oxygen and low water flows) that become more prevalent along their western range compared to other species (Gough and others, 2012; NatureServe, 2020). Dramatic declines in abundance of the focal species have also been reported elsewhere in their range (for example, Haag, 2019).

\section{Dataset Limitations}

The baseline distribution maps for species in the freshwater mussel assemblage address a priority data need identified for the Southern Great Plains Rapid Ecoregional Assessment (Assal and others, 2015) and contribute to a priority research need for improved mapping of species distributions across a range of spatial scales (Freshwater Mollusk Conservation Society, 2016). There are several limitations of the source datasets, however, that are important to consider for dataset application and interpretation. As with all REA datasets, discontinuities across State boundaries can result from differences in source dataset methodology (Reese and others, 2017). For example, 
survey design, sampling intensity, and time periods varied markedly by State. Nonrandom sampling sites may have been spatially biased, for example, by accessibility. In addition, historical records available from the source datasets were limited, especially for Oklahoma, which also lacked information on survey dates. Many of the mussel occurrence records are several decades old, and some populations may have been subsequently extirpated, especially if occurrence within a subbasin was based on only a few records. The associated data release (Fancher and Carr, 2021) summarizes information on the number of occurrence records (range from 0 to 462), data source, and time periods for each species by subbasin (8-digit hydrologic unit code); this information can be useful for assessing uncertainty in the presence or absence of species at the subbasin or subregion level (see also table 5 for summaries by subregion) and may help to highlight potential data gaps.

Although life history guilds may be useful for developing management and conservation actions for freshwater mussels, there are also limitations when using guilds to generalize response patterns to other species within the same guild (Caro, 2010; Ries and others, 2016). In particular, the mussel assemblage includes only widespread species and, consequently, is not expected to be representative of the majority of the extant mussel fauna, which have very restricted distributions within the project area (table 4). Additionally, the distribution of host fish species needed for successful mussel reproduction is an important determinant of the distribution of mussel species (Galbraith and others, 2018) but is not addressed by more generalized life history traits (table 2). Use of the guild approach may be most appropriate for evaluating population-level changes for catchments with a narrow range of hydrologic conditions (for example, Galbraith and others, 2010; Allen and others, 2013) rather than at the subbasin level where a broader range of conditions suitable for diverse life history strategies is more likely to occur.

More detailed information on mussel abundance, density, and habitat conditions may be available at local catchment or watershed levels compared to regional datasets summarized by subbasin or subregion, but local studies lack the broader context provided by regional datasets. The limitations of data from local spatial extents (such as watershed or catchment) data and broad-scale data (such as ecoregions) can be minimized by using information from a range of scales to inform management activities (Reese and others, 2017). Because processes operating across a range of spatial extents can be important in structuring freshwater mussel communities, regional datasets may provide the broader context for localized studies (Vaughn, 1997). The use of multiscale data requires an understanding of the limitations and underlying assumptions of datasets from each scale.

\section{Summary}

There were 61 native species of freshwater mussels with documented occurrences within the three-State project area of Nebraska, Kansas, and Oklahoma. This includes 6 species that apparently have been extirpated from the project area and 6 species that apparently have been extirpated from at least one State but still occur elsewhere in the project area. There were 24 extant species in Nebraska, 42 in Kansas, and 48 in Oklahoma. Of the extant species, 8 are federally threatened or endangered and 5 are imperiled or vulnerable.

The freshwater mussel assemblage includes six species that were widely distributed (across more than one-quarter of the State) in Nebraska, Kansas, and Oklahoma. Amblema plicata (threeridge), Fusconaia flava (Wabash pigtoe), and Lampsilis cardium (plain pocketbook) occurred in approximately one-third of all subbasins and slightly more than half of the subregions. Lampsilis teres (yellow sandshell) and Uniomerus tetralasmus (pondhorn) were more widespread, occurring in close to half of the subbasins and about three-quarters of the subregions. Pyganodon grandis (giant floater) was the most widespread species, occurring in about three-quarters of subbasins and almost all subregions. There were very few subbasins with only historical occurrences. The three-State (subbasin- and subregion-level) distribution maps can serve as baseline information for monitoring future trends and provide the larger context for more detailed watershed- or catchment-level studies.

\section{References Cited}

Allen, D.C., Galbraith, H.S., Vaughn, C.C., and Spooner, D.E., 2013, A tale of two rivers - Implications of water management practices for mussel biodiversity outcomes during droughts: Ambio, v. 42, no. 7, p. 881-891. [Also available at https://doi.org/10.1007/s13280-013-0420-8.]

Allen, D.C., and Vaughn, C.C., 2009, Burrowing behavior of freshwater mussels in experimentally manipulated communities: Journal of the North American Benthological Society, v. 28, no. 1, p. 93-100. [Also available at https://doi.org/ 10.1899/07-170.1.]

Anderson, T., 2005, Uniomerus tetralasmus (pondhorn)-A technical conservation assessment: U.S. Department of Agriculture, Forest Service, Rocky Mountain Region, 33 p., accessed March 15, 2020, at https://www.fs.usda.gov/ Internet/FSE_DOCUMENTS/stelprdb5206810.pdf.

Angelo, R.T., Cringan, M.S., Hays, E., Goodrich, C.A., and Miller, E.J., 2009, Historical changes in the occurrence and distribution of freshwater mussels in Kansas: Great Plains Research, v. 19, no. 1, p. 89-126, accessed January 16, 2018, at https://digitalcommons.unl.edu/ greatplainsresearch/990/. 
Assal, T.J., Melcher, C.P., and Carr, N.B., eds., 2015, Southern Great Plains Rapid Ecoregional AssessmentPre-assessment report: U.S. Geological Survey Open-File Report 2015-1003, 284 p., accessed September 2015, at https://doi.org/10.3133/ofr20151003.

Carter, S.K., Carr, N.B., Miller, K.H., and Wood, D.J.A., eds., 2017, Multiscale guidance and tools for implementing a landscape approach to resource management in the Bureau of Land Management: U.S. Geological Survey OpenFile Report 2016-1207, 79 p., accessed January 2017, at https://doi.org/10.3133/ofr20161207.

Caro, T., 2010, Conservation by proxy-Indicator, umbrella, keystone, flagship, and other surrogate species: Washington, D.C., Island Press, 374 p.

Esri, 2014, ArcGIS desktop, Release 10.3: Redlands, Calif., Esri.

Fancher, T.S., and Carr, N.B., 2021, Distribution of a freshwater mussel assemblage in Kansas, Nebraska, and Oklahoma: U.S. Geological Survey data release, accessed February 8, 2021, at https://doi.org/10.5066/P9SBFZJU.

Freshwater Mollusk Conservation Society, 2016, A national strategy for the conservation of native freshwater mollusks: Freshwater Mollusk Biology and Conservation, v. 19, no. 1, p. 1-21. [Also available at https://doi.org/10.31931/ fmbc.v19i1.2016.1-21.]

Fritts, A.K., Fritts, M.W., Haag, W.R., DeBoer, J.A., and Casper, A.F., 2017, Freshwater mussel shells (Unionidae) chronicle changes in a North American river over the past 1000 years: The Science of the Total Environment, v. 575, p. 199-206. [Also available at https://doi.org/10.1016/ j.scitotenv.2016.09.225.]

Galbraith, H.S., Devers, J.L., Blakeslee, C.J., Cole, J.C., St. John White, B., Minkkinen, S., and Lellis, W.A., 2018, Reestablishing a host-affiliate relationship_-Migratory fish reintroduction increases native mussel recruitment: Ecological Applications, v. 28, no. 7, p. 1841-1852. [Also available at https://doi.org/10.1002/eap.1775.]

Galbraith, H.S., Spooner, D.E., and Vaughn, C.C., 2008, Status of rare and endangered freshwater mussels in southeastern Oklahoma: The Southwestern Naturalist, v. 53, no. 1, p. 45-50. [Also available at https://doi.org/10.1894/00384909(2008)53[45:SORAEF]2.0.CO;2.]

Galbraith, H.S., Spooner, D.E., and Vaughn, C.C., 2010, Synergistic effects of regional climate patterns and local water management on freshwater mussel communities: Biological Conservation, v. 143, no. 5, p. 1175-1183. [Also available at https://doi.org/10.1016/j.biocon.2010.02.025.]
Ganser, A.M., Newton, T.J., and Haro, R.J., 2015, Effects of elevated water temperatures on physiological response in adult freshwater mussels: Freshwater Biology, v. 60, no. 8, p. 1705-1716. [Also available at https://doi.org/10.1111/ fwb.12603.]

Gates, K.K., Vaughn, C.C., and Julian, J.P., 2015, Developing environmental flow recommendations for freshwater mussels using biological traits of species guilds: Freshwater Biology, v. 60, no. 4, p. 620-635. [Also available at https://doi.org/10.1111/fwb.12528.]

Global Biodiversity Information Facility, 2017a, Lampsilis teres: Global Biodiversity Information Facility web page, accessed September 15, 2017, at https://doi.org/10.15468/ dl.crsj5o.

Global Biodiversity Information Facility, 2017b, Uniomerus tetralasmus: Global Biodiversity Information Facility web page, accessed September 15, 2017, at https://doi.org/ 10.15468/dl.uvptb0.

Global Biodiversity Information Facility, 2018a, Amblema plicata: Global Biodiversity Information Facility web page, accessed June 19, 2018, at https://doi.org/10.15468/ dl.tlnhfs.

Global Biodiversity Information Facility, 2018b, Fusconaia flava: Global Biodiversity Information Facility web page, accessed June 19, 2018, at https://doi.org/10.15468/ dl.hljkwu.

Global Biodiversity Information Facility, 2018c, Lampsilis cardium: Global Biodiversity Information Facility web page, accessed June 19, 2018, at https://doi.org/10.15468/ dl.y2nhrz.

Global Biodiversity Information Facility, 2018d, Pyganodon grandis: Global Biodiversity Information Facility web page, accessed June 20, 2018, at https://doi.org/10.15468/ dl.hdau0e.

Gough, H.M., Gascho Landis, A.M., and Stoeckel, J.A., 2012, Behavior and physiology are linked in the response of freshwater mussels to drought: Freshwater Biology, v. 57, no. 11, p. 2356-2366. [Also available at https://doi.org/10.1111/ fwb.12015.]

Grabarkeiwicz, J.D., and Davis, W.S., 2008, An introduction to freshwater mussels as biological indicators-Including accounts of Interior Basin, Cumberlandian, and Atlantic Slope species: Washington, D.C., U.S. Environmental Protection Agency Office of Environmental Information, EPA-260-R-08-015, 122 p., accessed January 2018, at https://nepis.epa.gov/Exe/ZyPDF.cgi/P1002IYI.PDF? Dockey=P1002IYI.PDF. 
Haag, W.R., 2012, North American freshwater musselsNatural history, ecology, and conservation: New York, Cambridge University Press, 505 p. [Also available at https://doi.org/10.1017/CBO9781139048217.]

Haag, W.R., 2019, Reassessing freshwater mussel declines in the United States: Freshwater Mollusk Biology and Conservation, v. 22, no. 2, p. 43-60. [Also available at https://doi.org/10.31931/fmbc.v22i2.2019.43-60.]

Haag, W.R., and Warren, M.L., 2007, Freshwater mussel assemblage structure in a regulated river in the Lower Mississippi River Alluvial Basin, USA: Aquatic Conservation, v. 17 , no. 1, p. 25-36. [Also available at https://doi.org/10.1002/aqc.773.]

Haag, W.R., and Williams, J.D., 2014, Biodiversity on the brink-An assessment of conservation strategies for North American freshwater mussels: Hydrobiologia, v. 735, no. 1, p. 45-60. [Also available at https://doi.org/10.1007/s10750013-1524-7.]

Hoke, E., 2011, The freshwater mussels (Mollusca-BivalviaUnionoida) of Nebraska: Transactions of the Nebraska Academy of Sciences and Affiliated Societies, v. 32, p. 1-46, accessed January 16, 2018, at https://digitalcommons.unl.edu/ cgi/viewcontent.cgi?article $=1001 \&$ context=tnas .

Hopkins, R.L., II, 2009, Use of landscape pattern metrics and multiscale data in aquatic species distribution models - A case study of a freshwater mussel: Landscape Ecology, v. 24, no. 7, p. 943-955. [Also available at https://doi.org/ 10.1007/s10980-009-9373-5.]

Integrated Taxonomic Information System (ITIS), 2020, accessed May 28, 2020, at http://www.itis.gov.

Malish, M.C., and Woolnough, D.A., 2019, Varied physiological responses of Amblema plicata and Lampsilis cardium exposed to rising temperatures: Freshwater Science, v. 38, no. 4, p. 842-855. [Also available at https://doi.org/ 10.1086/706185.]

Mather, C.M., 2005, Freshwater mussels of Oklahoma: Oklahoma Department of Wildlife Conservation, 267 p., accessed April 29, 2019, at https://digitalprairie.ok.gov/ digital/collection/stgovpub/id/7475.

Miller, E.J., and Lynott, S.T., 2006, Increase of Unionid mussel populations in the Verdigris River, Kansas, from 1991 to 2003: Steuben, Maine, Southeastern Naturalist, v. 5, no. 3, p. 383-392. [Also available at https://doi.org/ 10.1656/1528-7092(2006)5[383:IOUMPI]2.0.CO;2.]
Mitchell, Z.A., McGuire, J., Abel, J., Hernandez, B.A., and Schwalb, A.N., 2018, Move on or take the heatCan life history strategies of freshwater mussels predict their physiological and behavioral responses to drought and dewatering?: Freshwater Biology, v. 63, no. 12, p. 1579-1591. [Also available at https://doi.org/10.1111/ fwb.13187.]

NatureServe, 2020, NatureServe Explorer [web application]: Arlington, Va., NatureServe, accessed May 13, 2020, at https://explorer.natureserve.org/.

Obermeyer, B.K., 1998, A comparison of quadrats versus timed snorkel searches for assessing freshwater mussels: American Midland Naturalist, v. 139, no. 2, p. 331-339. [Also available at https://doi.org/10.1674/00030031(1998)139[0331:ACOQVT]2.0.CO;2.]

Oklahoma Department of Wildlife Conservation, 2016, Oklahoma comprehensive wildlife conservation strategy-A strategic conservation plan for Oklahoma's rare and declining wildlife: Oklahoma City, Okla., Oklahoma Department of Wildlife Conservation, 418 p., accessed August 2019, at https://www.wildlifedepartment.com/sites/ default/files/Oklahoma\%20Comprehensive $\%$ 20Wildlife $\% 20$ Conservation\%20Strategy_0.pdf.

Popejoy, T., Randklev, C.R., Neeson, T.M., and Vaughn, C.C., 2018, Prioritizing sites for conservation based on similarity to historical baselines and feasibility of protection: Conservation Biology, v. 32, no. 5, p. 1118-1127. [Also available at https://doi.org/10.1111/cobi.13128.]

Reese, G.C., Burris, L., Carr, N.B., Leinwand, I.I.F., and Melcher, C.P., 2017, Southern Great Plains Rapid Ecoregional Assessment_-Volume I, Ecological communities: U.S. Geological Survey Open-File Report 2017-1100, 129 p., accessed December 2017, at https://doi.org/10.3133/ ofr20171100.

Reese, G.C., Carr, N.B., and Burris, L.E., 2018, Southern Great Plains Rapid Ecoregional Assessment-Volume II, Species and assemblages (ver. 1.1, December 2018): U.S. Geological Survey Open-File Report 2018-1109, 134 p., accessed December 2018, at https://doi.org/10.3133/ ofr20181109.

Ries, P.R., Newton, T.J., Haro, R.J., Zigler, S.J., and Davis, M., 2016, Annual variation in recruitment of freshwater mussels and its relationship with river discharge: Aquatic Conservation, v. 26, no. 4, p. 703-714. [Also available at https://doi.org/10.1002/aqc.2590.]

Rohweder, M.R., 2015, Kansas wildlife action plan: Kansas Department of Wildlife, Parks and Tourism, Ecological Services Section, in cooperation with the Kansas Biological Survey, 176 p., accessed August 2019, at https://ksoutdoors.com/Services/Kansas-SWAP. 
Schneider, R., Fritz, M., Jorgensen, J., Schainost, S., Simpson, R., Steinauer, G., and Rothe-Groleau, C., 2018, Revision of the tier 1 and 2 lists of species of greatest conservation need-A supplement to the Nebraska natural legacy project state wildlife action plan: Lincoln, Nebr., The Nebraska Game and Parks Commission, 96 p., accessed August 2019, at http://outdoornebraska.gov/wp-content/uploads/2018/ 09/NE-SWAP-SGCN-Revision-Supplemental-Document2018-Final.pdf.

Tweedy, N.T., 2015, Freshwater mussels species assemblage, chap. 10 of Assal, T.J., Melcher, C.P., and Carr, N.B., eds., 2015, Southern Great Plains Rapid Ecoregional Assessment-Pre-assessment report: U.S. Geological Survey Open-File Report 2015-1003, p. 104-117, accessed July 13, 2017, at https://doi.org/10.3133/ofr20151003.

U.S. Fish and Wildlife Service, 2020, ECOS [Environmental Conservation Online System] species data explorer: U.S. Fish and Wildlife Service website, accessed May 13, 2020, at https://ecos.fws.gov/ecp/report/adhoc-creator?catalogId= species\&reportId=species\&columns=\%2Fspecies@cn,sn, status,desc,listing_date.

U.S. Geological Survey and U.S. Department of Agriculture, Natural Resources Conservation Service, 2013, Federal standards and procedures for the National Watershed Boundary dataset (WBD) (4 ed.): U.S. Geological Survey and U.S. Department of Agriculture, Natural Resources Conservation Service, Techniques and Methods 11-A3, 63 p., accessed June 4, 2020, at https://pubs.usgs.gov/ $\mathrm{tm} / 11 / \mathrm{a} 3 /$.

Vaughn, C.C., 1997, Regional patterns of mussel species distributions in North American rivers: Ecography, v. 20, no. 2, p. 107-115. [Also available at https://doi.org/10.1111/ j.1600-0587.1997.tb00352.x.]
Vaughn, C.C., 2010, Biodiversity losses and ecosystem function in freshwaters - Emerging conclusions and research directions: Bioscience, v. 60, no. 1, p. 25-35. [Also available at https://doi.org/10.1525/bio.2010.60.1.7.]

Vaughn, C.C., 2012, Life history traits and abundance can predict local colonization and extinction rates of freshwater mussels: Freshwater Biology, v. 57, no. 5, p. 982-992. [Also available at https://doi.org/10.1111/j.13652427.2012.02759.x.]

Vaughn, C.C., 2018, Ecosystem services provided by freshwater mussels: Hydrobiologia, v. 810, no. 1, p. 15-27. [Also available at https://doi.org/10.1007/s10750-017-3139-x.]

Vaughn, C.C., Gido, K.B., and Spooner, D.E., 2004, Ecosystem processes performed by unionid mussels in stream mesocosms - Species roles and effects of abundance: Hydrobiologia, v. 527, no. 1, p. 35-47. [Also available at https://doi.org/10.1023/B:HYDR.0000043180.30420.00.]

Vaughn, C.C., and Spooner, D.E., 2004, Status of the mussel fauna of the Poteau River and implications for commercial harvest: American Midland Naturalist, v. 152, no. 2, p. 336-346. [Also available at https://doi.org/10.1674/00030031(2004)152[0336:SOTMFO]2.0.CO;2.]

Vaughn, C.C., and Taylor, C.M., 1999, Impoundments and the decline of freshwater mussels - A case study of an extinction gradient: Conservation Biology, v. 13, no. 4, p. 912-920. [Also available at https://doi.org/10.1046/ j.1523-1739.1999.97343.x.]

Williams, J.D., Warren, M.L., Cummings, K.S., Harris, J.L., and Neves, R.J., 1993, Conservation status of freshwater mussels of the United States and Canada: Bethesda, Md., Fisheries, v. 18, no. 9, p. 6-22. [Also available at https:// doi.org/10.1577/1548-8446(1993)018<0006:CSOFMO $>2$. $0 . \mathrm{CO} ; 2$. 
For more information concerning the research in this report, contact the

Center Director, USGS Fort Collins Science Center

2150 Centre Ave., Bldg. C

Fort Collins, CO 80526-8118

(970) 226-9100

Or visit the Fort Collins Science Center website at https://www.usgs.gov/centers/fort 
